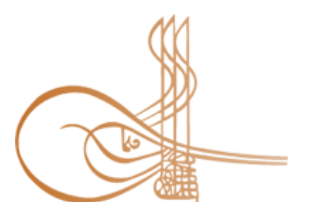

www.turkishstudies.net/religion
Turkish Studies - Comparative Religious Studies

eISSN: 2667-5544

Research Article / Araştırma Makalesi

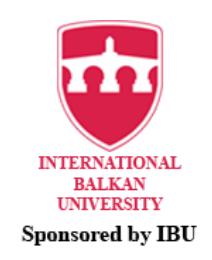

Sponsored by IBU

\title{
Cengiz Aytmatov'un Eserlerinde Öne Çıkan Varoluşsal Temalar
}

\author{
Existential Themes Prominent in Chingiz Aitmatov's Works
}

\author{
Erol Çetin ${ }^{*}$
}

\begin{abstract}
Chingiz Aitmatov appears as an important writer and thinker trying to deal with human existence in many ways in his works. Aitmatov, who evaluates the dimensions of human thought, feeling, emotion and will in a unique and authentic style, put forward remarkable ideas in terms of making sense of existence. What makes his works so important is that he can reach the universal from the national and local. In this context, Aitmatov was able to successfully express the common pains, joys, dreams, sorrows and longings of humanbeing in his works. Both his internalization of local values and virtues and his being very sensitive to the universal problems of humanity enabled him and his works to gain a completely different place in the hearts of people. Another point that makes Chingiz Aitmatov authentic is that the dynamism and vitality of existence is felt in a concrete way in almost every sentence of him. In this sense, every word and sentence dripping from Aitmatov's pen; it would not be wrong to say that life is a reflection of the traces left on itself. In this study, firstly, what kind of relationship between philosophy and literature is discussed, then basic information about the nature of the relationship between existentialist philosophy and literature is given. Then, the relevance of Chingiz Aitmatov's works to philosophy and existential philosophy is examined. In this context, the first in his works; Existential themes such as human, nature, God, freedom, alienation, war, father figure, suicide, fate, helplessness and evil is investigated within the framework of the existentialist philosophical approach, which has a very important place in the philosophy of religion.
\end{abstract}

Structured abstract: The philosophy of religion emerges as a field that has the potential to build bridges and to lean on almost every subject that concerns our existence. In this context, the philosophy of religion can play an important role in addressing the relationship between philosophy and literature. It is seen that literature, which is one of the most powerful means of expression in the effort to understand and explain humankind, is in a very close relationship with philosophy. The basic and indispensable factor of both literature and philosophy is human. Throughout the history, literature and philosophy have tackled with the universal human thought together. At this point, it is possible to say that philosophy and literature have common concerns in terms of making sense of existence, life and human.

Existential philosophy is the discipline in which we find concrete and striking examples of the relationship between philosophy and literature. Existentialism is defined as both a philosophical and a literary movement. Existentialism, which questions the meaning of life and tries to explain what it means to exist as a person in the world, focuses on the human being and draws attention to the human condition. Existentialism

\footnotetext{
* Dr. Öğr. Üyesi, Kahramanmaraş Sütçü İmam Üniversitesi İlahiyat Fakültesi, Felsefe ve Din Bilimleri Bölümü, Din Felsefesi Anabilim Dalı

Asst. Prof. Dr. Kahramanmaraş Sütçü İmam University, Faculty of Theology, Department of Philosophy and Religion Sciences, Department of Philosophy of Religion ORCID 0000-0001-7732-2487

erolcetin_er@hotmail.com

Cite as/ Atıf: Çetin, E. (2020). Cengiz Aytmatov'un eserlerinde öne çıkan varoluşsal temalar. Turkish Studies - Religion, 15(3), 297-322. https://dx.doi.org/10.47091/TurkishStudies.45752

Received/Geliş: 11 August/Ağustos 2020

Accepted/Kabul: 20 September/Eylül 2020

Checked by plagiarism software

Copyright C INTAC LTD, Turkey 
tries to capture the human image as a whole by gathering all the factors of human reality within a general human frame. Similarly, existential philosophy of religion addresses the existential problems of human beings such as anxiety, fear, guilt, sinfulness, responsibility, hope and despair, mortality, meaninglessness, loss, secularization, fallenness, alienation, liberation and authenticity. In this context, it can be said that novel and other forms of expression are one of the most basic ways of conveying the experiences of human existence reflected on life in existential philosophy.

Chingiz Aitmatov is an important writer who managed to draw attention to both literature and intellectual field, and emphasizes existential themes in his works. In this context, it can easily be stated that Aitmatov made serious efforts to analyze the meaning and depth of existence. In addition to being a good literary artist, he is also an important thinker who managed to make existential explanations about issues such as existence, the meaning of existence, human, fate, religion, freedom, death, alienation, loneliness, despair and evil. Therefore, evaluating his works and his views that are put forward to understand the nature of human being within the framework of existential philosophical approach will have an important function in understanding Aitmatov's world of thought better.

The philosophy of religion is a branch of science that has the potential to build bridges between fields such as philosophy and religion, ethics, aesthetics, and literature, and to take on almost any subject that concerns our existence. In this study, the relationship between philosophy-literature in general, existentialist philosophy of religion in particular and the literary works of Chingiz Aytmatov was examined, and it was concluded that philosophy and literature have common concerns in terms of making sense of human, world and existence. Because both fields basically aim to explain the issues of human and existence with a unique method.

In this study, the Kyrgyz writer Chingiz Aytmatov, one of the important figures of contemporary Turkish thought, is the subject of his literary works; It has been seen that the problems such as human, God, nature, freedom, alienation, war, father figure, suicide, helplessness, destiny and evil are very close to each other. In this context, it has been observed that existential themes in Aytmatov's works are handled in a depth that can be called philosophical.

Chingiz Aitmatov is more than just a writer, he is a wise person. He has managed to internalize the irony and dynamism of existence in his self. The most concrete example of this is the existential depth of the subjects he deals with in his works. In this context, the author placed human at the center of literature, saw God as the sacred being worshiped by all people living on the earth, analyzed nature and living creatures in a completely different depth, emphasized that freedom is the main factor of being a human, he mentioned that people who are alienated from their self and turned into a mankurt lost their honor, he informed us about the nature of the irreparable wounds in the human soul caused by the war, revealed that the lost father is a continuous bleeding wound that cannot be filled in the human self, showed that suicide represents a true existence by rebellion against evil rather than destruction, the feeling of helplessness, he emphasized that it was not possible to avoid fate and claimed that people made the world an uninhabitable place because of the evil they did.

As a result, it can be said that Chingiz Aytmatov tries to deal with the issues he has dealt with in his works with a universal consciousness. In this context he; approached man, the world and all beings in the world with a wise spirit. Aitmatov has a deep love for human beings, for nature, in short, for everything that exists. He has been trying to capture the meaning and depth of existence throughout his life. These and similar features, which we tried to express throughout our study, justify our emphasis on the handling of his works and thoughts within the framework of existential philosophy of religion.

Keywords: the philosophy of religion, Chingiz Aitmatov, philosophy, literature, existentialist philosophy.

Öz: Cengiz Aytmatov, eserlerinde insan varoluşunu birçok açıdan ele almaya çalışan önemli bir yazar ve düşünür olarak karşımıza çıkmaktadır. İnsanın düşünce, duygu, his ve irade boyutlarını kendine özgü bir üslupla değerlendirmeye tabi tutan Aytmatov, varoluşu anlamlandırma noktasında dikkate değer fikirler ileri sürmüştür. Onun eserlerini bu denli önemli kılan şey, milli ve yerel olandan evrensele ulaşabilmesidir. Bu bağlamda Aytmatov tüm insanlığın ortak acılarını, sevinçlerini, hayallerini, hüzünlerini ve özlemlerini eserlerinde oldukça başarılı bir şekilde ifade etmiştir. Hem yerel değerlerini bütün benliğinde içselleştirmesi 
hem de insanlığın evrensel sorunlarına karşı çok hassas olması onun ve eserlerinin insanların gönlünde bambaşka bir yer edinmesini sağlamıştır. Cengiz Aytmatov'u özgün kılan diğer bir husus ise onun neredeyse her bir cümlesinde varoluşun dinamizmi ve canlılığının somut bir şekilde hissediliyor olmasıdır. Bu anlamda Aytmatov'un kaleminden damlayan her bir kelimenin, cümlenin; hayatın kendisinde bıraktığı izlerin birer yansıması olduğunu söylemek yanlış olmayacaktır. Bu çalışmada öncelikle felsefe-edebiyat arasında ne tür bir ilişki olduğu ele alınmış akabinde varoluşçu felsefe ile edebiyat arasındaki ilişkinin mahiyeti hakkında temel bilgiler verilmiştir. Daha sonra ise Cengiz Aytmatov'un eserlerinin felsefe ve varoluşçu felsefeyle alakası irdelenmiştir. Bu bağlamda ise onun eserlerinde önce çıkan; insan, tabiat, Tanrı, özgürlük, yabancılaşma, savaş, baba figürü, intihar, kader, çaresizlik ve kötülük gibi varoluşsal temalar din felsefesinde çok önemli bir yere sahip olan varoluşçu felsefî yaklaşım çerçevesinde incelenmiştir.

Anahtar Kelimeler: din felsefesi, Cengiz Aytmatov, felsefe, edebiyat, varoluşçu felsefe.

\section{Giriş}

Din felsefesinin en önemli karakteri köprüler kurabilme potansiyelidir (Alpyağıl, 2014:29). Bu bağlamda din felsefesinin felsefe ve edebiyat arasındaki ilişkiyi ele alma noktasında da önemli bir görev üstlenebileceğini söylemek mümkündür. Bu çalışma, eserleri ve ortaya koyduğu görüşleriyle hem edebiyat hem de düşünce sahasında dikkatleri üzerine çekmeyi başarmış olan ünlü Kırgız yazar Cengiz Aytmatov'un duygu ve düşünce dünyasında öne çıkan varoluşçu temaları, din felsefesinde önemli bir yere sahip olan "varoluşsal felsefî yaklaşım" çerçevesinde incelemeyi hedeflemektedir.

İnsanı anlama ve anlatma çabasında en güçlü ifade aracı edebiyattır. İnsan varoluşunda yer alan her şey edebiyatın da içinde yer alır (Taşdelen, 2014: 207). Edebiyat, diğer sanatlar içerisinde felsefeye en yakın olanıdır. Edebiyatın da felsefenin de temel ve onsuz olunmaz nesnesi insandır. $\mathrm{Bu}$ bağlamda her iki alan da farklı yollardan, insana ilişkin bilgimizin sınırlarını genişletmek suretiyle kendilik bilincimizin boyutlarını derinleştirme ve zenginleştirmeyi hedefler (Yetişken, 2012:75). Buradan hareketle varoluşu, hayatı ve insanı anlamlandırma noktasında felsefe ve edebiyatın ortak kaygılara sahip olduklarını söylemek mümkündür.

Roman ve diğer ifade tarzlarının varoluşçu felsefede insan varoluşunun hayata yansıyan tecrübelerini aktarabilme noktasında en temel yollardan biri olduğu söylenebilir (Koç, 2015:115). Varoluşçuluk, insan realitesinin tüm unsurlarını genel bir insan çerçevesi içinde toparlamak suretiyle bir bütün olarak insan imajını yakalamaya çalışmıştır (Barrett, 2003: 27). Aynı şekilde varoluşsal din felsefesi de kayg1, korku, suçluluk, günahkârlık, sorumluluk, umut ve umutsuzluk, ölümlülük, anlamsızlık, kaybolmuşluk, dünyevileşme, düşmüşlük, yabancılaşma, kurtuluş ve otantiklik gibi insanın içinde bulunduğu somut yaşantı durumlarını diğer bir ifadeyle varoluşsal sorunları kendisine problem edinir (Tokat, 2018a: 35). Bu bağlamda varoluşçu felsefe ve edebiyat arasında, insanın varoluşsal boyutlarını ve mahiyetini en ince detaylarıyla ortaya koyma noktasında çok sıkı bir ilişkinin var olduğu rahatlıkla ifade edilebilir.

Cengiz Aytmatov iyi bir edebiyatçı olmasının yanı sıra eserlerinde ele almaya çalıştı̆̆ varoluş, varoluşun anlamı, insan, kader, din, özgürlük, ölüm, yabancılaşma, yalnızlık, çaresizlik ve kötülük gibi konularla ilgili varoluşsal izahları da yapmayı başarabilmiş önemli bir düşünürdür. Bu sebeple onun eserlerinin ve insanın mahiyetini anlamaya yönelik ileri sürmüş olduğu görüşlerinin varoluşçu felsefi yaklaşım çerçevesinde değerlendirmeye tabi tutulması, Aytmatov'un düşünce dünyasını daha iyi anlama noktasında önemli bir işleve sahip olacaktır.

\section{Felsefe - Edebiyat İlişkisi}

Dil ve söz, insanın her varoluşsal yöneliminde kaçınılmaz olarak yer almaktadır. Zira insan, dil sayesinde varlıkla bağ kurar. Yani var olan da kendisi de dil içinde varlık kazanır. İnsan bunu edebiyatla birlikte yapabilir (İyi, 2014: 145-146). Edebiyat, varlık ve hayata ilişkin kavrayışın belli 
bir dil ve söylemle dışlaştırılmasıdır (Koç, 2013:17). Sadece malumattan ibaret olmayan felsefe de her şeyden önce gerçekliğe, düşüncelere yönelik bir bakış ve yaşam biçimidir. Bir duyuş, algılayış, kavrayış, düşünme tarzıdır (İnam, 2009:137).

Felsefe ve edebiyat gerçeği arayan, gerçeği bildiren idrake dayalı etkinliklerdir (Murdoch, 2015:45). Aynı insani varoluş alanında bulunan felsefe ve edebiyatın insani bütünlüğü yansıtmaya çalıştıkları görülür (Taşdelen, 2013:69). Bu noktada bir olanaklar bütünlüğü halinde var olanı dile getirme ve gösterebilmeyi amaç edinen edebiyat, diğer sanat dalları arasında felsefeye en yakın olanıdır. Edebiyat, insanın yapı olanaklarını ve insan sorunlarını somutlaştırarak bunların canlandırılmış yaşantılar ve eylemlerle gösterilmesini sağlar. Böylece edebiyat, insanın dünyasına özgü olan çeşitliliğin hem temelleriyle birlikte hem de en geniş ve en derin bağlantıları içinde düşünsel, algısal ve duygusal boyutlarda dile gelebilmesine vesile olmaktadır (Yetişken, 2012:7475). Edebiyat, bu manada insanla ilgili tüm duyarlılıkların, insanlık durumlarının felsefesidir (Timuçin, 2014:40).

Edebiyat ve felsefe birbirine yakın olan sahalardır. Bu bağlamda çoğu yerde edebiyatın felsefe tadı verdiği, felsefenin ise zaman zaman edebiyata çaldığ 1 görülür. Yani edebiyat ve felsefe arasında çoğu zaman gözümüzden kaçan, ilk bakışta farkına varamadığımız bir ilişki vardır. Bu noktada iyi felsefenin aynı zamanda iyi bir edebiyat, iyi edebiyatın ise her zaman iyi bir felsefe olduğu söylenebilir (Timuçin, 2014:31) Edebiyat ve felsefe tarihten bu yana evrensel insan düşüncesini birlikte dokumuş, birlikte örmüş, birlikte işlemiştir. Örneğin ünlü düşünür Platon, filozof olmadan önce bir edebiyat adamıdır. Buradan hareketle edebî söylem ile felsefî söylem arasında birbirini besleyen ve zenginleştiren bir bağ olduğu rahatlıkla ifade edilebilir (İyi, 2014:149). Yukarıda değinilen hususlardan da anlaşılacağı üzere aslında edebiyat kavramıyla felsefe kavramını incecik bir sınır birbirinden ayırmaktadır (Timuçin, 2014: 36-37).

Felsefî düşünce bütün insani alanda etkisini gösterir (Tokat, 2013a:12). Bu bağlamda felsefi faaliyet sadece epistemolojik olmayıp insan olmanın getirdiği zihinsel ve varoluşsal bir faaliyettir (Tokat, 2018a:17). Felsefe insan dünyasında karşılık bulduğu ölçüde anlamlıdır (Taşdelen, 2015:21). Zira özgün bir felsefî çabanın yaşam dünyasının verilerinden yararlanmayı bilmesi gerekir (Taşdelen, 2015:110). Buradan hareketle gündelik hayatla felsefe arasında nasıl bir ilişki varsa felsefe ve edebiyat arasında da öyle bir ilişkinin var olduğu rahatlıkla ifade edilebilir (Taşdelen, 2013:70). Günümüzde artık edebiyatın felsefeyi ve felsefenin de edebiyatı etkilediği herkes tarafından kabul edilen bir gerçekliktir (Sarı, 2016:6).

Edebiyatın dünyayı yorumu ile felsefenin yorumu etkileşime girebilir. Diğer bir ifadeyle; felsefe edebiyatı, edebiyat felsefeyi besleyebilir (İyi, 2014:169). Görüldüğü üzere felsefe ve edebiyat birbirini dişlayan değil, aksine tamamlayan, destekleyen ve hatta kimi durumda birbirlerini içeren tutumlardır. Dikkatle bakıldığında büyük filozofların eserlerinde bir ifade gücü olarak edebiyatın, büyük edebiyatçıların eserlerinde ise bir derinlik olarak felsefenin bulunduğu görülür (Taşdelen, 2013:9). Bununla birlikte felsefi eserin soyut, edebi eserin ise somut olduğu gerçeği de göz ardi edilmemelidir. Çünkü, insan hayatı, onun varoluşu ve özgürlüğü gibi hususların felsefenin diliyle anlaşılması pek mümkün değildir. Bu durumda sanat devreye girer ve felsefeye somutluk kazandırır (Gündoğan, 2014b:55). Felsefenin dili kavramlardır. Ancak hiçbir kavramın yukarıda da vurgulandığı üzere bireyin seçimlerini, kaygılarını, özgürlüklerini belirlemesi ve ifade etmesi mümkün görünmemektedir. Zira bireysel insan varoluşu, aklın ürettiği kavramı aşan bir yapıya sahiptir (Gündoğan, 2014c:70)

Felsefe ile edebiyat arasındaki ilişkinin kendi kültür tarihimiz açısından değerlendirilmesi de önem arz etmektedir. Çünkü Türk insanının dünyaya, hayata ve bütün varlıklara karşı aldığı tavır, felsefî bir sistematiğe bürünmüş olmaktan ziyade edebîdir. Bununla birlikte edebiyatımızın ürünlerinin Türk felsefesinin oluşması, gelişmesi ve zenginleşmesi açısından hayati öneme sahip olduğunu unutmamak gerekir (Gündoğan, 2014b:62). Gelişmiş bir edebiyat felsefe dilinin 
oluşmasına büyük ölçüde katkı sağlar (Gündoğan, 2014c:67). Bu noktada kültürel birikimimizin, efsanelerimizin, masallarımızın, türkülerimizin felsefî bir bakış açısıyla yeniden okunması, bir birikim ve zenginlik olarak görülmelidir (Taşdelen, 2015:23). Zira destanlar, masallar, kıssalar, öyküler, romanlar, insani varoluşun hem düşünsel-duygusal yönlerini yansıtan hem de içerisinde felsefi öğeler barındıran edebi ürünler olarak karşımıza çıkmaktadır (Koç, 2015:115). Örneğin “Manas Destanı", Ramazan Korkmaz'ın da vurguladığı üzere ölümlü insanı, toplumsal tine taşımak suretiyle ölümsüzlüğe kavuşturan bir araç olarak değerlendirilmektedir (Korkmaz, 2016:85). Yukarıda ele alınan hususlardan da rahatlıkla anlaşılacağı üzere edebi anlatılar; gerçekliği anlamak ve algılatmak noktasında hiçbir suretle göz ardı edilemeyecek ve hayatlarımıza etki ederek varoluşsal arayışlara cevaplar verebilen kıymetli eserlerdir. Recep Alpyağıl'ın da belirttiği üzere anlatılar çoğu durumda saf hakikatten daha etkin olabilmekte ve dağınık bir biçimde duran eylemlerden bir bütün oluşturmamızı sağlamak suretiyle yaşamlarımıza anlam katmaktadır (Alpyağıl, 2014:113-114).

\section{Varoluşçu Felsefe - Edebiyat İlişkisi}

Varoluş̧̧u felsefe temel mesajlarından birçoğunu roman, drama, günce vb. yoluyla verebilen felsefeyle edebiyat ilişkisinin yoğun ve çok önemli örneklerini gördüğümüz bir alan olarak karşımıza çıar (Koç, 2015:114). Bu noktada varoluşçuluğun hem felsefî hem de edebî bir hareket olarak tanımlandığı görülür (Taliaferro\&Marty, 2010:83). Hayatın anlamını sorgulayan, (Tokat, 2013a:119) dünyada bir insan olarak var olmanın ne olduğunu açıklamaya çalışan (Cevizci, 2005:1695) varoluşçuluk, insana odaklanır ve insanın durumuna dikkat çeker (Reese, 1980:163-164). Merkezine insanı alan egzistansiyal düşünce (Magill, 1992:21) bireysel varoluşu araştırmalarının temeline koyarak, insanın öznelliği ve özgürlüğü üzerine vurgu yaparak onun özgür seçimleriyle kendini var ettiğini vurgular. (Koç, 2018:795). Bu bağlamda varoluşçu filozofların insanı bireysel orijinalitesi ve kendine özgü yaşam biçimiyle biricik bir varlık olarak değerlendirdikleri söylenebilir (Koç, 2015:114).

Modernizmle birlikte Avrupa bilimi, insan yaşamını teknik ve mekanik bir inceleme nesnesine dönüştürerek yaşam dünyasının bilimin ufkunda kaybolup gitmesine neden olmuştur. İnsanoğlu, günümüz dünyasında bilgi açısından hiç olmadığ 1 kadar ileriye gitmiş olsa da dünyayı ve kendi benliğini bir bütün olarak görebilme kabiliyetinde o denli geri kalmıştır. (Güven, 2014: 179). Örneğin rasyonalizmin, insanı soyut kavramlarla ve akıl yürütmelerle anlamaya çalıştığ 1 , insanı mantıksal bir sürecin ürünü olarak görerek insanın bireyselliğini ve şahsiliğini yok ettiği iddia edilmiştir (Gündoğan, 2014b:59). Bu bilgilerden hareketle beşerî tecrübede yaşanan bölünmelerin çağımızın en çetin problemi olduğu rahatlıkla ifade edilebilir (Aydın, 1999:270).

Özgürlük, irade, sorumluluk, ölümlülük, yabancılaşma, suç, ölüm gibi özel ve tanımlanması zor yoğun duygular, Kierkegaard'dan bu yana varoluşçuların çoğu tarafından bariz bir şekilde ele alınır (Macquairre, 1973:209). ${ }^{1}$ Varoluşçuluk rasyonalizmin aksine insan hayatı ve varoluşuna ilişkin sorunları somut ve şahsi hayatlar üzerinden ele alır. Varoluşun sistemini kurmak, bazı noktalarda aklı aşan hayatın tasvirini yapmak mantıkî olarak akıl yürütmeye uygun düşmediğinden varoluşu şahsi ve somut örnekler üzerinden tasvir etmek, canlı bir dil kullanarak daha anlaşılır kıllmak için edebiyata ihtiyaç duyulur (Gündoğan, 2014a:7). Edebiyatın sonsuz cümle kombinasyonları ve varlık alanları, geniş metafor ve anlatım dili (Sarı, 2016:89-90) varoluşu izah etme noktasında çok önemli bir işleve sahiptir. Sonuç olarak belirtmek gerekirse edebiyat insanı, sadece düşünen değil aynı zamanda çılgınlıkları, duyguları, heyecanları ve aşırılıkları olan bir varlık olarak değerlendirmek suretiyle bilimin başaramadığ şeyi yapar (Gündoğan, 2014c:72).

Bir edebî esere felsefece bakmak onda felsefece bir şeyler aramak çok önemlidir (Gürsoy, 2014a:173). Edebiyat yapıtlarını, felsefi bir okuyuşla besleyip felsefi bir iklim içinde

\footnotetext{
${ }^{1}$ Varoluşçuluğun mahiyeti hakkında geniş bilgi için bkz. John Macquairre, Existentialism, Pelican Books, New York 1973, ss.1-17.
}

www.turkishstudies.net/religion 
soluyabildiğimiz gibi felsefe yapıtlarını da edebî bir okuyuşla, edebiyat ikliminde yaşayabilmemiz gerekir (İnam, 2014:168). Zira edebiyat felsefeyle bütünleştiği zaman, hayatı içselleştirebileceğiniz metafizik tecrübeyi size yansıtabilir. Bu bağlamda ekzistansiyel alana ilişkin kılmak, içselleştirmek, derûnileşmek ve böyle bir çabayı edebî biçimde ifade edilebilmek, felsefî-edebî olmak için yeterlidir (Gürsoy, 2014a:175-176). Varoluşçu düşünürler, felsefenin metafizik boyutunun ancak romanda kendini gösterebileceğini vurgular. Çünkü metafizik boyut ancak insan hayatında, insan hayatının tek olan tecrübeleriyle ortaya çıkmaktadır. Bu noktada insan artık evrensel-soyut bir kavram olmayıp her birimizin kendi içimizde yaşattığımız veya doğrudan yaşadığımız aktüel bir varoluş halinde olacaktır (Gürsoy, 2014b:46).

Yukarıda ele alınan hususlardan hareketle edebiyat-felsefe ilişkisinin, edebi zevki fikre, fikri de edebi zevke feda etmeden karşılıklı olarak her iki sahanın birbirinden faydalanmasını temel alan bir zeminde değerlendirilmesinin daha sağlıklı olacağı sonucuna varılabilir. Bu bağlamda da edebiyat ile felsefe arasındaki ilişkinin en güzel örneklerinin varoluşçu filozoflarda bulunduğu söylenebilir (Gündoğan, 2014a:7).

\section{Cengiz Aytmatov'un Eserlerinin Varoluş̧u Felsefeyle İlişkisi}

Cengiz Aytmatov, varoluşçu temalara vurgu yapan bir düşünürdür. $O$, varoluşa ve insana dair hususları roman, hikâye ve yazılarında felsefî bir derinlikle ele alabilmiştir. Bu bağlamda Aytmatov'un edebi eserlerinde konu edindiği insan, din, Tanrı, tabiat, özgürlük, kader, yabancılaşma, ölüm, yalnızlık, çaresizlik, intihar, kötülük gibi yaşama dair temel olgular veyahut problemler varoluşçu felsefi yaklaşım çerçevesinde ele alınabilme imkânına sahiptir.

Edebi metinler, hayatı ve insanı anlamamıda her zaman önemli bir yere sahip olmuşlardır (Taşdelen, 2014:432). Bir edebiyat eserinin bu anlamda dünyada ve orada bulunuşumuza ilişkin birinci elden bir yorum olduğu söylenebilir (Koç, 2013:9). Her edebiyat eserinin temelinde bir düşünce, bir kavram, evrensel nitelik gösteren bir duygu vardır. Bu yüzden her edebiyat eseri az ya da çok felsefî bir değerde ortaya çıkar (Taşdelen, 2013:84-85). Diğer bir ifadeyle her roman, her öykü, çizdiği tiplerin orjinalliği, canlılığı, derinliği oranında felsefî bir nitelik kazanır (Taşdelen, 2013:78). Özellikle varoluşçu felsefede kavramlar canlı olup bir yaratım, bir süreç ve bir olay teşkil ederler. Yani varoluşçulukta felsefe yaşamın içinde yapılır ve sanat, siyaset, bilim, toplumsal sorunlar vb. felsefenin dışında görülmezler (Alpyağıl, 2016:30). Varoluşçu yaklaşım; deneme, makale ve düz yazı tarzının yerine ağılıklı olarak roman, hikâye, piyes ve aforizma gibi edebî türleri kullanmayı tercih etmektedir (Ertürk, 2012:130). Bu bağlamda edebiyat ve felsefe arasındaki ilişki en yoğun şekilde varoluşçuluk söz konusu olduğunda ortaya çıkmakta ve bu yoğunluktan dolay1 felsefe ile varoluşçu roman özdeşliği bile gündeme gelmektedir (Gündoğan, 2014b:58).

Çağdaş varoluşçuluğun felsefe anlayışı, merkezine insanı alır. Varoluşçu felsefi yaklaşımda insan ve insani olana son derece önem ve ayrıcalıklı bir konum atfedilir. Varoluşçu yaklaşım, insanın varoluşunu sadece onun aklına veya bedenine indirgemeyip onu bedeni, ruhu, akl1, hisleri, duyguları, tutkuları, iradesi, kararları ve eylemleriyle, kısacası tüm yönleriyle bir bütün olarak ele alır (Ertürk, 2012:113-115). ${ }^{2}$ Kuru ve spekülatif akademik konuları bir kenara bırakan varoluşçu yaklaşım, bunların yerine somut bireysel insan varoluşunu doğrudan ilgilendiren pratik konuları felsefenin merkezine alıp bunların analizlerini yapmaya çalışır (Ertürk, 2012:119). Varoluşçu yaklaşımda kavramsal bazlı ve literal nitelikli sistematik argümantatif dil ve üsluba yer verilmez. Bunun yerine, genel olarak sembol, paradoks, ironi, trajedi, istiare, mecaz, sezgisel/şiirsel söylem vb. türden dolaylı anlatım ve ifade şekillerini ihtiva eden, fazla sistemlilik kaygısı gütmeyen bir üslup tercih edilir (Ertürk, 2012:129-130).

\footnotetext{
${ }^{2}$ Varoluşçu felsefi yaklaşım hakkında geniş bilgi için bkz. Ramazan Ertürk, Varoluşsal Din Felsefesine Giriş, Yarın Yayınlar1, İstanbul 2012, ss.113-130.
} 
Varoluş̧̧u felsefi yaklaşım, insanın duygu ve his dünyasına çok büyük önem atfetmekte ve onları felsefenin en önemli konuları olarak görmektedir (Ertürk, 2012:120). Bu noktada varoluşçu filozoflar insan varoluşunun aşk, acı, umut, umutsuzluk, ihanet, sadakat, özgürlük gibi temel deneyimlerini roman kahramanlarıyla temsil etmeye çalışır. Romanlarında orijinal, canlı, yaşayan karakterler yaratmak suretiyle insan varoluşunun ahlaki ve metafizik derinliğine dikkat çekerler (Koç, 2015:115). Bu noktada Cengiz Aytmatov'un roman ve hikâyelerinde oluşturduğu ana karakterler vasıtasıyla vermek istediği evrensel nitelikli mesajlar da bu çerçevede değerlendirilebilir.

Cengiz Aytmatov, felsefi odaklı bir edebiyatı arzu ettiğini belirtir (Yılmaz, 2015:55) Onun eserlerinde kelimeler, cümleler ve misraların arasında güzel kokulu felsefe havası kendini dolu dolu hissettirir (Yağmur, 2008:53). Felsefi boyutlar taşıyan edebiyat sorgulayan, eleștiren ve insanın duygu ve düşünce dünyasında yeni ufuklar açan bir edebiyat olarak karşımıza çıkar. Bu manada her büyük edebiyat eserinin, bir anlamda bir düşünce eseri olduğunu söylemek mümkündür (Güney, 2014:266-267). Aytmatov'un eserleri, dünyayı tanımada felsefi görüşlerin sınırlarını genişletir ve derinleştirir (Akmataliyev, 1998:93). Cengiz Aytmatov dünyası herkesin dünyasıdır, insanlığın dünyasıdır ve bu dünyanın penceresi insanlığı seven, özgürlüğü destekleyen herkese sonuna kadar açıktır (Kazımoğlu, 1994:34). Aytmatov, dünyanın hiç kimsenin göremeyeceği dertlerini, acılarını ve problemlerini görüp bunları dünya halklarına iletmeye çalışmıştır (Kazımoğlu, 1994:30). Onun felsefî, estetik, eğitici güzel, kanatlı düşünce ve görüşleri çok kıymetlidir (Akamtaliyev, 1998:118). Özellikle çağdaş dünyada karşı karşıya kalınan problemlere dikkat çeken Aytmatov, (Jeziorska, 1991:62) evrensel sorunlara evrensel açıdan bakmaya çalıştığını vurgular (Aitmatov, 1988:143). Ona göre bilim ve teknolojinin etkisi altında kalan insanın bilincinde, ruhunda ve ruhsal yaşamında çok önemli değişiklikler meydana gelmektedir (Aitmatov, 1988:145). Kullandığı üslup, eserlerindeki kahramanlar ve değindiği konularla insanların yüreğine dokunmayı başardığını belirten Aytmatov, bütün insanları ilgilendiren konulara değindiği için sevildiğini vurgular (Yılmaz, 2015:75). O, genel olarak insanı diğer bir ifadeyle evrensel anlamda insanı ele alır (Yılmaz, 2015:54).

Bir sanat eseri, yarattığı tipin gücü, derinliği ve evrenselliği ile insan varoluşunu temsil etme kapasitesi ölçüsünde güçlüdür (Taşdelen, 2013:74). Halkının sosyal gerçeklerinden ve kültürel, geleneksel değerlerinden yola çıkan Aytmatov, eserlerini bu köklü yapılar üzerinde temellendirmek suretiyle bütün insanlığa ulaşmıştır (Erbay, 2002:29). Diğer bir ifadeyle o, milli hissiyatı bütün insanlığ1 kucaklayan ortak zevk, estetik ve duyarlık haline dönüştürmeyi başarmıştır (Kolcu, 1997:37). Aytmatov'un eserlerinde tüm dünyanın ortak acılarının edebiyata getirildiği görülür (Kazımoğlu, 1994:27). İlgili eserlerde, basit edebi bir dille anlatılan insanın trajedisinden bütün dünyanın trajedisine, mahalli trajediden global trajediye dek uzanan mecazla yüklü derin felsefi bir trajedinin olduğu bariz bir şekilde görülür (Asanova, 2008:54).

İnsanoğlunun ufkunu açıp genişletmek felsefenin en temel amaç ve işlevlerinden birisidir (Ertürk, 2012:86). Aytmatov, kendi felsefi bakış açısıyla romanlarının dünyasını genişletir ve olayları evrensel boyuta taşıyarak günümüz dünyasının bazı temel meselelerini irdeler. O, "Dişi Kurdun Rüyaları" adlı eserinde günümüz dünyasının içinde bulunduğu çıkmazın bir inanç boşluğundan kaynaklandığı, insanın ahlaki ve manevi değerlerini kaybetmesi yüzünden dünyanın yaşanması güç bir yer haline geldiğini vurgular (Gökçek, 2004:93). "Kassandra Damgası" adlı eserinde ise insanları dünyanın bozulmuşluğu karşısında düşünmeye çağırır (Yılmaz, 2007:75). Aytmatov, medeniyet ve ilerlemenin insanları mutlu edeceği yerde daha da köleleştirdiğini iddia eder (Kolcu, 1997:148). Ona göre bazı insanlar ahlaki ölçütlerden tamamen yoksun kalmak suretiyle vicdanlarını kaybetme noktasına gelmiştir (Aitmatov, 1988:154).

\section{Cengiz Aytmatov'un Eserlerinde Öne Çıkan Varoluşçu Temalar}

Yabancılaşma, insan yaşamının özünde kırılgan ve bağımlı oluşu, aklın varoluşun derinlikleri karşısında güçsüz olması, yok olma korkusu, hiçlik tehdidi karşısında bireyin yapayalnız ve çaresiz oluşu gibi hususlar varoluşçuluk tarafindan konu edinilen temel problemlerdir (Barrett, 
2003:42). Bu bağlamda Cengiz Aytmatov'un eserlerinde; insan, tabiat, Tanrı, özgürlük, yabancılaşma, savaş, baba figürü, intihar, kader, çaresizlik ve kötülük gibi varoluşsal temaların konu edinildiğini söylemek mümkündür.

Aytmatov, içinde yaşadığı yüz yıl ve yaşam koşullarından dolayı yukarıda değinilen varoluşsal sorunları kendine has bir bakış açısıyla değerlendirmeyi başarabilen özgün bir yazardır. Stalin diktası tarafından kurşuna dizilen ve bir ömür yolları beklenen "kayıp baba" imgesi, ikinci dünya savaşının her aileye yokluk ve ölüm getiren uğursuz yılları, benliğine ve öz değerlerine yabancılaşmış mankurt yetiştirme paronayası gibi felaketler, Cengiz Aytmatov'un gerçek anlamda varoluş sorunu ile yüzleşmesine neden olmuştur (Korkmaz, 2016:13-14). Buradan hareketle Aytmatov'un hayatı ile eserlerinin muhtevaları arasında gözle görülür bir benzerliğin olduğu, (Yılmaz, 2007:66) yaşama dair temel problemleri felsefî bir derinlikle varoluşsal çerçevede ele aldığ 1 söylenebilir.

Cengiz Aytmatov'a göre insanoğlu öteden beri insanın kaderi, erdem ve hataları, mücadele ve savaşları, aşk ve ayrılıkları, doğum ve ölüm, kısaca hayatın her parçasını şarkılar, peri masalları, kitaplar, müzik ve oyunlarla farklı dil ve lehçelerde hikâye etmiştir (Aitmatov, 1988:9). O, yaşamın çeşitliliğini felsefî açıdan yansıtmayı yazarın akidesi olarak görür (Akmataliyev, 1998:117). Aytmatov'da hiçbir konu bir roman veya hikâyede sona ermez sürekli devam eder (Söylemez, 2010a:14). Buradan hareketle Aytmatov'un hayatı boyunca varoluşun anlam ve derinliğini yakalamaya çalıştığ 1 , onun eserlerinde varoluşçu temaların kendini yoğun bir şekilde hissettirdiği rahatlıkla ifade edilebilir.

\section{1.İnsan}

Felsefe esasında insan gerçeğini irdelemeyi gaye edinir (Gürsoy, 2013:91). Varoluşçuluk ise insanın bireysel varoluşunu merkezine alır (Maclntyre, 1967:147) ${ }^{3}$ ve insanın varoluşuna bir değer atfeder. Zira bizatihi varoluş değerlidir (Tokat, 2017:20). Evrende yer alan bir varlık olarak insan dış dünyayı sadece tecrübe etmekle kalmaz ona hayranlıkla yönelir, onu güzel bulur ya da ondan korkup kaçmaya çalışır. Bunların hepsi içerisinde değer yargıları, anlamlar ve yorumlar barındıran bir tecrübedir (Işık, 2016:392). Aynı şekilde insan her çağda ve her yerde; sevgi, arzu, sahiplenme, barınma, korunma, sığınma ve hâkim olma duygusuyla yaşar. Sevinçlerini ve acılarını paylaşmak ister. Hayatta elde ettiği kazanımlarının elinden gitmesini istemez (Korkmaz, 2016:162). Kısaca yaşama dair hedef ve gayeleri olan insan anlam ve değer olmaksızın yaşayamaz (Tokat, 2018b:334).

Cengiz Aytmatov'un eserlerinde insan, yukarıda da değinildiği üzere varoluş esprisinin bütün gizemini içinde barındıran bir varlık olarak karşımıza çıkar. Zira evrende insan kadar birbirine zit değerlerden meydana gelen bir varlık daha yoktur (Korkmaz, 2016:216). Aytmatov, edebiyatın temel, değişmez gayesinin insan ruhunun özünü yansıtmak olduğuna inanır (Kala, 2019:26). Bu bağlamda $\mathrm{o}$, hem insanın yüreğinde derin izler ve acılar bırakan sarsıcı duygu çatışmalarını hem de insan gerçeğini etkileyici bir şekilde ele almayı başarır (Erbay, 2002:317). "Dişi Kurdun Rüyaları" adlı eserinde varoluşumuzun mahiyetine yönelik şu değerlendirmelerde bulunur: "Varlığımızın tanımını yapmak zordur. Sayısız ilişkiler arasında yine sayısız kombinezonlar kurulur. İnsanların karakterleri o kadar karmaşıktır ki, en gelişmiş, en hassas bir bilgisayar, en normal insanlar arasında bile ortak bir davranış eğrisi çizemez" (Aytmatov, 2014ç:42).

Aytmatov'un düşünce dünyasında insan odak noktasıdır. Ona göre bir yazarın asıl işi, insanı anlatmaktır (Erbay, 2002:119). O, edebiyatının kalbine dünyanın özlem duyduğu 'insan'ı yerleştirir (Kala, 2019:29). Eserlerinde insanı bütün yönleriyle ve derinlemesine inceler (Şakiyeva, 2009:138). Gayesi insanı bilmek, insanı bulmak ve insanı korumaktır (Kala, 2019:31). Aytmatov, insan

\footnotetext{
${ }^{3}$ Varoluşçu temalar hakkında geniş bilgi için bkz. Alasdair Maclntyre, "Existentialism”, The Encyclopedia of Philosophy, Vol. 3, Ed. by Paul Edwards, London: Collier-Macmillan Ltd., 1967, ss.147-149.
} 
yaşamının temel sorularına varoluşsal bir bakış açısıyla cevap aramayı hedefler (Akmataliyev, 1998:92). Bu bağlamda o; zaafları, iniş ve çıkışlarıyla insanı çok iyi analiz eder (Yılmaz, 2007:54). Aytmatov, yaşanan acı ve sıkıntıları anlamlandırmaya çalışırken insan gerçeğini derinden yakalar (Buran, 2009:34). İnsanın varoluşsal özelliklerini özgün bir bakış açısıyla değerlendirmeye tabi tutar.

Cengiz Aytmatov'un eserlerinde insan ve onun varoluş biçimleri temel problem olarak ele alınır. O, insanın zaman ve mekânla değişmeyecek olan asli yönlerini anlatır. Aytmatov'un insanlığın bütün sevinç ve acılarını bizatihi kendinde deneyimleyerek yansıttığını söylemek mümkündür (Korkmaz, 2009a:16-18). O, bütün insanlığı yakından ilgilendiren olayları, ortak acı ve sevinçleri evrensel bir bakış açısıyla ele alır. Bu manada onun eserlerinde yer alan isim ve mekânlar değiştirilip yerlerine dünyanın herhangi bir yerindeki isim ve mekanlar konulduğunda fazla bir şeyin değişmediği sonucun her türlü insana ve iyisiyle kötüsüyle insana ait olana çıktığı görülür (Oymak, 2010:161). Ona göre insanı merkeze almayan şeylerin manası yoktur. Aytmatov, evrenin tek sorumlu canlısı olan insanın varlığının bilincinde olması gerektiğine inanır (Yılmaz, 2015:95). O, insani değerleri evrensel boyutta ele almak suretiyle ideal dünyaya ulaşmak ister. İdeal dünyaya ulaşmanın ana şartı ise ideal bireyler yetiştirmektir. Zira sadece insan olmanın idrakine varmış kişiler ideal birey olabilir (Koçak, 2010:89). Bu bağlamda Aytmatov, her insanın içinde var olan insancıllık, merhamet ve vicdan gibi duyguları geliştirme, insanlara iyi davranma, onları sevme, onlara iyi dileklerde bulunma gibi değerleri yüceltmek gerektiğini vurgular (Özer, 1976:413).

Aytmatov, eserlerini insanı merkeze alan bir yaklaşımla kaleme almıştır. Örneğin "Kassandra Damgası" adlı eserinde insan yaşamının geleceğine yönelik duyduğu kaygı ve endişeyi s1k s1k vurgular (Koçak, 2010:86). Düşünürümüz, eserin en önemli karakterlerinden biri olan Futurolog Robert Bork üzerinden insanlığın içine düştüğü çıkmazları ve sorunları dile getirmeye çalışır. Bu bağlamda Robert Bork, zekâ ve evrensel misyona sahip olan insanın kendini mükemmelleştirmek için gayret göstermesi gerektiğini zira bunun insanın varlık sebebi olduğunu belirtir. Bu çabada olmayan insanları görevini yapmayan bir asalak, hiçbir işe yaramayan alçaklar olarak değerlendirir (Aytmatov, 2017b:54). Bork, bilim ve teknikte kazanılan tüm başarılara rağmen insanların kendine benzer varlıkları yiyen hayvan olarak kaldıklarını dahi iddia eder (Aytmatov, 2017b:98).

Aytmatov, insanın varoluşsal özelliklerini ele aldığı "Dişi Kurdun Rüyaları" adlı eserinde de insanın huzura kavuşup ruhunu aydınlatabilmesi için kendi benliğini keşfetmesi gerektiğini vurgular (Aytmatov, 2014ç:87). Aynı şekilde "Deve Gözü" adlı hikayesinde insanın yaptıklarının bir anlamı olması ve yaptığı şeylerden mutluluk duyabilmesi için her şeyden önce insan olduğu gerçeğinin bilincinde olması gerektiğini ifade eder (Aytmatov, 2014f:124). Bu bağlamda "Beyaz Gemi” adlı romanında insandaki çocuk vicdanını tohumdaki öze benzeten Aytmatov, öz olmadan tohumun filizlenip gelişemeyeceğini belirtir (Aytmatov, 2014a:168). Kısaca Aytmatov, ruhu olgunlaştırıp mükemmel hale getirmeyi insanın varoluş sebebi olarak görür. Ona göre hayatta insan için en yüce amaç bu olmalıdır. Zira hayatın, varoluşun anlam ve güzelliği buradadır (Aytmatov, 2014ç:198).

Aytmatov'un insanı varoluşsal açıdan ele aldığı değerlendirmelerinden hareketle onun son nefesine kadar insanlığı uyarmaya çalıştığını, insanoğlunu gereksiz kavga ve tartışmalardan kurtarmak istediğini, insan olduğumuz gerçeğinin bilincinde olup bunun gerektirdiği şekilde davranış sergilememiz gerektiğini sürekli olarak bizlere hatırlatma çabasında oluğunu söyleyebiliriz (Oğuz, 2008:82).

\section{Tabiat}

Tabiat insanın duygu, düşünce dünyasının oluşumu ve gelişimi ile karakterinin şekillenmesinde önemli bir role sahiptir. İçinde yaşadığı evrene duyarlı ve sorumluluğunun bilincinde olan bir kişi, insanlara ve tabiatta bulunan diğer canlılara karş1 engin bir merhamet duygusuna sahip olur. Cengiz Aytmatov tabiata karşı çok hassas olup onu varoluşsal bakış açısıyla ele almayı başarabilmiş bir yazardır. Onun eserlerinde çevreye ve diğer canlılara verilen önem 
doğrudan göze çarpar. Öyle ki Aytmatov'un eserlerinde tabiat, bir ilham kaynağı olmakla birlikte varoluşun destekleyici ve dengeleyici unsuru olarak karşımıza çıkar. Bu bağlamda Aytmatov'un düşünce dünyasının inşasında tabiatın önemli bir etken olduğunu söylemek mümkündür.

İnsanın kendisiyle ve kendini kuşatan evrenle uyum içerisinde yaşaması gerekir. Zira insanın gerçek anlamda mutluluğa ulaşması buna bağlıdır (Kolcu, 2008:7). İnsanın tabiatla bütünleşmesinin lüzumunu vurgulayan (Jeziorska, 1991:45) Aytmatov'un insan merkezli yaklaşımında çevreciliğin önemli bir yere sahip olduğu görülür. Bu bağlamda o, doğayla nasıl bir ilişki içerisinde yaşanması gerektiği sorusuna cevap arar (Mignon, 2009:110). Onun eserlerinde toprak, tabiat, bitki, hayvan, mitoloji, tarih, dün, bugün, gelecek, uzak gelecek gibi konular ana tema olarak ele alınır. Bütün bu hususların üstünde ise insanlığı barış ve huzura ulaştıracak olan "sevgi" yi işler (Söylemez, 2010b:36).

Aytmatov'un eserlerinde insanla tabiat arasında sıkı bir ilişki söz konusudur (Kolcu, 2008:16). Bu bağlamda onun, toprakla insanı aynileştirdiğine, tarihi olanla hali birleştirdiğine şahit oluruz (Kolcu, 1997:38). Onun eserlerinde toprak, varoluşsal derinliğe sahip bir unsur olarak karşımıza çıkar. Aytmatov için toprak birden fazla anlam katmanına sahiptir. Diğer bir ifadeyle toprak onun nazarında; tarih, kültür, istikbal, yürekten kâinata açılan pencere, kendini idrakin şuuru, her şeyle yoğrulmuş bir "ana", "toprak ana" demektir (Kolcu, 1997:85). Örneğin "Gün Olur Asra Bedel" romanında konu edilen Ana-Beyit, toprağa olan bağl1lığ , toprak sevgisini ve geçmişin şimdi ile buluşup anlam kazanmasını simgeleyen bir kimliktir (Deveci, 2009:251).

İnsan ve tabiat arasındaki ilişkinin varoluşsal derinliği Aytmatov’un birçok eserinde kendini gösterir. "Deniz Kıyısında Koşan Ala Köpek" adlı hikâye insanın doğayla olan münasebetinin ne denli hayati bir öneme sahip olduğunu bizlere anlatır. Adı geçen hikâyede doğanın sağduyulu refleksine güvenen insanın, en zor durum ve koşullardan onun işaret ve yardımı sayesinde kurtulduğu görülür. Bu bağlamda denizde sislerin ortasında kaybolan ve ölümle yüz yüze gelen Kirisk’i karaya, yani hayata döndüren güç, doğanın ihanet edilmemiş yanını simgeleyen Aguk kuşudur. Doğa, Aguk kuşu vasıtasıyla tüm çarelerin tükendiğinin sanıldığı bir noktada bunalan insanı, tekrar yaşama çağırır ve ona sığınak olur (Korkmaz, 2016:196). Aytmatov aynı hikâyede benliğinin şuurunda olan insanın tabiatla olan ilişkisinin varoluşsal açıdan ulaşabileceği derinliğin mahiyeti hakkında şunları söyler:

Kayıktaki insan evrenin sonsuzluğu karşısında bir hiç olduğunu çok iyi anlıyordu. Ama insan düşünürdü, düşüncesiyle Denizin ve Gögün yüceliğine erişirdi. Ve yüce düşüncelerinde, doğa güçleriyle evrenin derinliği ve yüksekliği ile bir tutardı kendini. İşte bu yüzden insan, yaşadıkça deniz kadar gökyüzünün sonsuzluğu kadar yüce ve güçlü olacaktır. Çünkü düşünceler sonsuzdur. O öldüğü zaman, bir başka insan onun düşüncelerini daha ileriye, sonra bir başkası ondan da ileriye götürecek ve bu sonsuza kadar böyle sürüp gidecektir (Aytmatov, 2013:109).

Aytmatov insanların tabiata zarar vermesine büyük tepki gösterir. Tabiatın pervasızca tahrip edilmesinden kaynaklı olarak dünyanın dengesinin bozulduğunu ve bunun insanlığı bekleyen en önemli tehlikelerden biri olduğunu iddia eder (Kolcu, 2008:11). Bu bağlamda o, insanoğlunun kendi felaketini bizzat kendi eliyle hazırladığını belirtir. Aytmatov, son romanı olan "Kassandra Damgası" adlı eserinde tamamen bu soruna odaklanır. Ona göre doğal çevreyi tahrip eden insanoğlu bitip tükenmek bilmeyen ihtiraslarıyla kendi hazin sonunu hazırlamaktadır (Kolcu, 2008:14).

"Beyaz Gemi” adlı romanda tabiattan, gelenekten, köklerinden ve benliğinden kopan insanın yer yüzünde var olma imkanını kaybederek tükeneceği vurgulanır. İnsanın yeniden var olma ve yeniden doğuşunun ancak tabiata, geleneğe, tarihe ve benliğine dönüşle gerçekleşebileceği belirtilir (Gariper\&Küçükcoşkun, 2009:187). Aytmatov “Dişi Kurdun Rüyaları" adlı eserinde insanın doğaya baş kaldırışını ve varoluşsal açıdan tabiattan kopuşunu konu edinir (Jeziorska, 1991:60). Ona göre büyük topraklar, geniş ufuklar, hava ve bol 1şı insanı tatmin edememiştir. İnsanoğlu her zaman şikâyet etmeyi tercih etmiştir (Aytmatov, 2014ç:161). Aynı şekilde Aytmatov "Kassandra Damgası" adlı romanında Uzay Rahibi Filofey karakteri üzerinden insanların evrene verdiği zararlara vurgu 
yapar. Bu bağlamda Filofey, insanların sırf kendi ihtiyaçlarını karşılayıp arzularını tatmin etme uğruna içinde yaşadıkları çevreye her türlü saldırıyı yaptıklarını öne sürer. İnsanlara, dünyanın çok büyük bir tehlikeyle karşı karşıya olduğunu bildirmek ister (Tüzer, 2009:320).

Yukarıdaki değerlendirmelerden hareketle ifade etmek gerekirse insanoğlu doğal çevreyi bırakıp yapay arzularının peşinde koşarak hayallerini tüketmiş ve kendi benliğinden uzaklaşmıştır. Ekolojik düzenin bozulmasıyla birlikte dünya yaşanması çok zor bir yer haline gelmiştir. Yeni dünya düzeni içerisinde sıradanlaştırılan, hayalleri ellerinden alınan ve arzularının esiri haline getirilen bireyler giderek çağdaş bir köle veya robot insan şekline bürünmüşlerdir. Kısaca Aytmatov'a göre, hayatı her anlamda doğal olandan yapay olana doğru sürüklenen ve benliğini inşa eden öz değerlerini yitiren insan neslini çok ciddi sorunlar beklemektedir (Kanter, 2009:312-314).

\section{Tanrı}

Cengiz Aytmatov'un eserlerinde Tanrı, yücelik algılamalarının merkez imgesi olarak karşımıza çıkar (Korkmaz, 2016:217). Ona göre Tanrı, kendisine dua ve ibadet edilendir. İnsanların kaderini ve alemlerin hareketini Tanrı belirler (Aytmatov, 2014c:37). Aytmatov, ilk çalışmalarında daha çok Gök Tanrı inancından izler taşıyan bir doğa dini motifi çizerken, sonraki eserlerinde ağırlıklı olarak semavi dinlerin Tanrı figürünü kullanır. $\mathrm{O}$, tüm dini yönelişlerin, insanlığı ortak bir yaratıcı imgede bütünleștirdiği inancındadır. Ancak bu Tanrı düşüncesi statik, değișmez ve tamamlanıp bitirilmiş bir tanımlama değildir. Aksine kişiyle beraber gelişip olgunlaşmaya gereksinim duyan bir açılımdır. Bu bağlamda o insanın, Tanrı'yı bir cevher olarak içinde taşıdığı ve bu cevherin, herkesin idraki, kavrayış gücü oranında anlam kazandığını vurgular (Korkmaz, 2016:217-218).

Aytmatov'un din ve Tanrıyla alakalı görüşlerine yoğun şekilde yer verdiği eserlerinden birisi "Kassandra Damgası"'dır. Adı geçen eserde Aytmatov, Robert Bork karakteri üzerinden Tanrı'ya ve dinlere yönelik temel görüşlerini ortaya koyar. Bork'a göre çeşitli dini öğretilerin gerçeğin sadece kendi tekellerinde olduğu yönündeki taraflı ve bencil iddiaları inançlı kitlelerin birbirlerinden nefret etmesine neden olmaktadır. Robert Bork, Tanrıya inanan her bir insanın dünyada yer alan tüm dinlere eşit olarak inanma hürriyetine sahip olması durumunda insanların hayatının olumlu yönde değişebileceğini, insanların yaşamlarının daha rahat ve dengeli olabileceğini düşünür. $O$, Tanrıya inancında kimseye yabancı olmadığı kimsenin de kendisine yabancı olmadığına inanır. Bu bağlamda duaların hepimizi aynı derecede işiten, kötülüklerimizden aynı derecede rahatsız olan, yaptığımız iyiliklere göre kâinatın kapılarını hepimize eşit bir şekilde açan Yaradan'a yöneldiğini belirtir. Bork'a göre böyle bir anlayıșa sahip olmak Tanrı fikrini zayıflatmaz. Aksine bu fikre evrensellik, açıklık ve dinamiklik kazandırır (Aytmatov, 2017b:104-106).

Aytmatov, "Gün Olur Asra Bedel" adlı romanında ise Yedigey karakteri üzerinden din ve Tanrıya dair fikirlerini açıklar. Yedigey inançlı bir Müslümandır. O, Tanrı'nın kendi içinde yaşayan bir cevher olduğuna inanır. Ona göre dualar, insanı hem Tanrıya hem de bizzat kendi benliğine yaklaştırır. Yedigey yaratıcı ve yaşatıcı olan Tanrıya sevgiyle bağlıdır. Ona dua ederken aslında kendisine yöneldiğini hisseder. Böylelikle yaratıcı, bă̆ışlayıcı ve esirgeyici olan Tanrıyı içselleştirir. (Korkmaz, 2016:204-206). Bu bağlamda Kazangap'ın cenaze töreninde Yedigey Allah'a şöyle dua eder:

Bilinen bir gerçektir ki insanlar Sana ancak çaresiz kalınca yardım dilemek için başvuruyorlar ve ellerinden başka bir şey gelmiyor. Bize acı, bizi koru, bize yardım et Allah'ım. İnsanlar, doğru olsun, yanlış olsun, haklı olsun haksız olsun, her şeyi Sen'den isterler. Bir katil bile içinden, Sen'in onun yanında olmanı ister. Oysa sen hep susarsın. Neyleyim ki biz insanlar böyleyiz ve Sen'i özellikle başımız darda olduğu zaman hatıllarız, yalnız böyle zamanlarda varmışsın sanırız. Yalvarıp yakarmalarımızın sonu gelmiyor. Sen 'Bir'sin. Biz ise çoğuz. (Aytmatov, 2014e:412-413).

Cengiz Aytmatov'un Tanrı'yla alakalı görüşlerine yoğun bir şekilde yer verdiği eserlerden biri de "Dişi Kurdun Rüyaları" dır. Bu eserde düşünürümüz mevcut Hristiyanlığa karşıt 
görüşlerinden dolayı papaz okulundan uzaklaştırılan teoloji öğrencisi Abdias karakteri üzerinden din ve Tanrı'ya yönelik görüşlerini ortaya koyar. Abdias, "Tanrı ve insan” anlayışının modern dünyadaki en önemli ve en heyecanlı konu olacağı görüşündedir. Ona göre endüstri sonrası çağda insan ve Yaradan arasındaki ilişkinin yeniden tanımlanması gerekecektir (Aytmatov, 2014ç:47). Bu bağlamda Abdias'ın, Tanrı- insan münasebetini yeniden kurmaya çalıştığı söylenebilir. O, çağdaş insanın ihtiyaçlarına cevap veremediği için her türlü dogmaya, eskimiş ve köhnemiş düşünceye, (Kolcu, 1997:210) insanları köleleştirme üzerine kurulmuş olan dünyadaki sisteme angaje olduğu için her türlü kötülük ve haksızlığı sükutla karşılayan kiliseye karşı çıkar (Gökçek, 2004:102).

Abdias'a göre teolojinin varlığını koruyabilmesi ancak dünyadaki bütün inançların odak noktası olan yeni bir Tanrı anlayışının ortaya çıkmasıyla mümkün olabilecektir (Aytmatov, 2014ç:96). O, Tanrı'nın düşünce ve sözlerimizde olduğunu, (Aytmatov, 2014ç:120) bütün insanlığın Tanrı'nın bu dünyadaki bir imajı ve görüntüsü olduğunu ve insanlığın Tanrı'nın bir cevheri olduğunu iddia eder (Aytmatov, 2014ç:200). Abdias'a göre bilincimizin ve vicdanımızın dışında bir tanrı yoktur (Aytmatov, 2014ç:101).

Aytmatov'un din ve Tanrı ile alakalı görüşlerinin daha anlaşılır kılınabilmesi için İslam inancına sahip olan Yedigey ile teoloji eğitimi alan Abdias karakterlerinin mukayese edilmesi faydalı olacaktır. Bu bağlamda Yedigey'de Tanrı ve iman probleminin olmadığını söylemek mümkündür. Zira o çok sınırlı bilgisine rağmen dogmaların, inançsızlığın ve ateizmin hâkim olduğu bir toplumda samimi bir Müslüman olarak inancını yaşamaya çalışır. Buna karşın Abdias, Hristiyanlık ve kendi inanç doktrini arasında kararsız ve çaresiz kalmış bir teoloji öğrencisi olarak kendisine muhatap bulamadığı için çıldırma noktasına gelir (Kolcu, 1997:218-219). Ayrıca "Dişi Kurdun Rüyaları" adlı romanda dikkat çekilen yukarıda bir kısmına değinmeye çalıştığımız problemlerin İslam'a ait bir inanç sapmasından kaynaklanmadığı da unutulmamalıdır. Bu noktada Abdias'ın içinde bulunduğu inanç bunalımı ve tereddütlerinin İslami inanç sistemi içerisinde değerlendirilmesi çok büyük bir hata olacaktır. Zira Abdias'ın içinden çıkamadığ 1 problemlerin makul ve tatmin edici cevapları İslamiyet'te zaten mevcuttur (Kolcu, 1997:224).

Sonuç olarak ifade etmek gerekirse Aytmatov dinlere eşit mesafede yaklaşır ve insanları mensup oldukları dine göre ayrıma tabi tutmaz (Akmataliyev, 1998:127). İnsanın yarattığı çöküntü, materyalizm, içki, uyuşturucu ve diğer olumsuzluklarla mücadelede dini inancın önemini vurgular (Jeziorska, 1991:61). Ona göre din bireyler tarafından özgürce yaşanmalı ve art niyetli insanların dini kullanmalarına izin verilmemelidir (Y1lmaz, 2015:100). Kısaca Aytmatov, hayatı boyunca tüm dinlere saygılı olmayı esas alan bir yaklaşıma sahip olmuştur (Yılmaz, 2015:85).

\section{4.Özgürlük}

Özgürlük, irade ve sorumluluk gibi temaların varoluşçu yaklaşımda öne çıkan unsurlar olduğu görülür. Bu konular bireysel varlığın özünü oluşturur. Özgürce hareket etmek ve geleceğini şekillendirebilmek, insanı yeryüzünde bilinen diğer bütün varlıklardan farklı kılmaktadır (Macquairre, 1973:4). Zira insanlar, özgür bir şekilde kendi seçimlerini yaptıkları ölçüde gerçekten kendileri olabilir (Macquairre, 1973:161). Buradan hareketle özgürlüğün olmadığ yerde anlamlılıktan bahsetmenin pek mümkün olmadığı söylenebilir (Tokat, 2013b:22). Cengiz Aytmatov, insanın özgürlüğüne çok önem verir. Onun neredeyse bütün eserlerinin temel zeminini hürriyet problemi oluşturur (Kolcu,1997:101). Aytmatov'a göre aydın insan toplumun özgürlüğü için mücadele etmeyi kendisine görev bilmelidir (Y1lmaz, 2015:90).

Hürriyet duygusu Aytmatov'un eserlerinin çevresinde döndüğü ana izlek olarak karşımıza çıkar. Hürriyet kavramını bireysel, toplumsal, milli ve manevi hürriyete kadar çok geniş bir perspektifte ele alan düşünürümüz insanlığ kuşatan dogmalar ve totaliter zorbalıkların karşısına insanlık onurunu çıkarır (Kolcu, 2008:38). Aytmatov, geçmişten günümüze insanların aynı tarzda düşünmelerini isteyen, insanın kişiliği ve bireyselliğini yok etmeye çalışan sömürgeci ve egemen güçlerin tahakkümüne artık insanların baş kaldırdığını vurgular (Yılmaz, 2015:94). İnsanın hür 
olmas1 gerektiğine değinen Aytmatov devir ve şartlar ne olursa olsun insanın özgürlüğünün kutsal olduğu inancindadır (Kolcu, 2008:122).

Aytmatov dünyanın, zamanın, toplumun ve diğer kişilerin istediği gibi mi yoksa kendi istediğimiz gibi mi yaşamalıyız sorusuna cevap aramaya çalışır (Korkmaz, 2009a:18). Ona göre insan, her şeyi tahakkümü altında bulunduran merkezin yönlendirmelerine göre düşünür ve eylemde bulunursa kendisi hakkında hiçbir fikri olmaz. Bu bağlamda özgür eylem alanını yitiren insan, gelecekteki varlığını da yaratamaz (Korkmaz, 2016:24).

Aytmatov "Gün Olur Asra Bedel” adlı romanında insanın özgürlüğü konusunu varoluşsal bir çerçevede ele almaya çalışır. İlgili romanda özgürlük sorunu, varoluşsal açıdan iki şekilde kendini gösterir. Bunlardan ilki, bireyin kendi bilincinden uzaklaşmasından dolayı kendine, dünyaya ve çevresine yabancılaşması; ikincisi ise düşünsel ve eylemsel düzlemde kendi benliğine sahip çıkan bireyin değerler dünyasını özgürce inşa etmek istemesidir (Deveci, 2009:248).

Kendilik bilincinin yarattığı değerlerin yerine baskın gücün istediği düşünce sistemlerini koymak, bireysel özgürlükleri feda etmek demektir (Deveci, 2009:255). Bu bağlamda irade ve özgün eylem tasarımlarından yalıtılan kişi, epistemik anlamda postulata dönüşmüş bir birey olur. Var gibi görünen ancak esasında var olmayan bu 'yokkişi'ler, otomat makineler gibidir. Bu yüzden onların insanlıkları bile tartışılır hale gelir (Korkmaz, 2016:43). Görüldüğü gibi insanın değerler dizgesinden kopartılması sadece bireyin değil dünyanın da sonunu getirecek olan evrensel nitelikli bir varoluş sorunudur (Korkmaz, 2016:92-93). Varoluşsal özgürlükleri yok sayılarak yaratıc1lıkları ellerinden alınan insanlar Juan Juanlar tarafindan mankurtlaştırılan Colaman örneğinde olduğu gibi benlik bilinçleri silinmek suretiyle ötekileştirilir. Ötekileştirme, varoluşsal anlamda bir özgürlük sorunudur. Zira ben bilincinden yoksun bırakılarak ötekileştirilen insan köle haline gelmektedir (Deveci, 2009:252).

Kendi benliğini inşa etmeye çalışan birey dünya, çevre ve kendisiyle bütünleşmek suretiyle yaşamın anlamsızlığından kurtulup bir bütünün parçası olur. "Gün Olur Asra Bedel” romanının öne çıan isimleri diyebileceğimiz Yedigey, Kazangap ve Abutalip karakterleri bu bütünün parçaları olmaktan mutludur. Zira onlar, yaşamın anlamını, dünya ve çevre ile kurmuş oldukları ilişkide bulur. Kendi benliğinin farkında olan bu bilinçli insanlar ortak gayeyle meydana getirdikleri toplumsal yapı içerisinde oldukları için özgürdür. Çünkü onlar özgürlüğün etkin katılımla gerçekleştirilebilen varoluşsal bir değer olduğuna inanırlar (Deveci, 2009:252).

\section{Yabancılașma}

Cengiz Aytmatov'un eserlerinde sürekli olarak işlediği varoluşsal temalardan bir tanesi de yabancılaşmadır. İnsanın bütün boyutlarını varoluşsal bakış açısıyla ele almaya özen gösteren düşünürümüzün eserlerinde, özgün bir birey olmanın önemine sık sık vurgu yaptığı görülür. Bu bağlamda varoluşçu düşünürlerin varoluşu anlamlandırma noktasında ortaya koymuş oldukları otantik ve inotantik varoluşla ilgili görüşlerine biraz daha yakından bakmak faydalı olacaktır.

Varoluşçu düşünürler, varoluşu "otantik" ve "inotantik" şeklinde iki forma ayırır (Flew, 1979:108). Onlara göre yaşamın bizi sürü haline getirmesine boyun eğdiğimizde hayatımız inotantik hale gelir ve gerçekten kendimize ait olmaz. Otantik olmak ise bir birey olarak varoluşumuzun netlik ve yoğunluğunu üstlenebilmek demektir (Guignon, 2000:265). Diğer bir ifadeyle otantik varoluş, kendini tanıma, kendini bilme, başkası gibi olmama, taklit etmeme, potansiyellerini kullanma, özgür olma, birey olma, ne yaptığının bilincinde olma, kendini tesadüflere ya da akıntıya bırakmama ama en önemlisi kim olduğunu, nasıl ve niçin yaşadığını bilme olarak açıklanabilir (Tokat, 2017:100). Kısacası otantik olmak kendi olmak demektir (Alpyağıl, 2014:37). Kendine yabancılaşan insan kim olduğunu ve anlamının ne olduğunu tekrar keşfedebilmelidir. (Barrett, 2003:181). Bu bağlamda insan özgürlüğü ve verdiği kararların sorumluluğunu üstlenebilmesi sayesinde otantik bir birey olur 
(Macquairre, 1973:4). ${ }^{4}$ Korku içindeki insansa kendisini dünyada kaybeder. Sürekli olarak kendisinden ve varoluşun sorumluluklarından kaçar (Tokat, 2013a:120). Aytmatov anlatılarındaki esas kurgu da kendilik bilinci olmayan insanla, anlam arayıc1/aktarıcı insan arasındaki çatışma üzerine bina edilir. Bu ikili çatışma yapısının, hemen hemen bütün Aytmatov anlatılarının özünü oluşturduğunu söylemek mümkündür (Korkmaz, 2016:71).

Aytmatov'un yabancılaşmayla ilgili görüşlerinin anlaşılmasındaki kilit nokta mankurtlaşma kavramıdır. O, "Gün Olur Asra Bedel" romanında mankurtlaşmanın mahiyeti hakkında şu bilgileri verir:

Ana-Beyit mezarlığının bir efsanesi, Juan-Juanlar'ın bozkırı işgal ettikleri çağlara dayanan bir hikayesi vardı: insanın hafızasını yitirmesine, deli olmasına yol açan bir işkence usulleri varmış. Önce esirin başını kazır, saçları tek tek kökünden çıkarırlarmış. Bunu yaparken usta bir kasap oracıkta bir deveyi yatırıp keser, derisini yüzermiş. Derinin en kalın kısmı boyun kısmı imiş ve oradan başlarmış yüzmeye. Sonra bu deriyi parçalara ayırır, taze taze, esirin kan içinde olan kazınmış başına sımsıkı sararlarmış. Böylece sarılan deri, bugün yüzücülerin kullandığı kauçuk başlığa benzermiş. Buna "Deri geçirme işkencesi” derlermiş. Böyle bir işkenceye maruz kalan tutsak ya acılar içerisinde kıvranarak ölür, ya da hafizasını tamamen yitiren, ölünceye kadar geçmişini hatırlamayan bir mankurt, yani geçmişini bilmeyen bir köle olurmuş. Mankurt, eski vücuduna saman doldurulmuş bir korkuluktan, bir mankenden farksız olurmuş onlar için (Aytmatov, 2014e:147-148).

Mankurtlaşma psikolojik ve felsefî anlamlarıyla insanın kendi özüne yabancılaşmasıdır (Mignon, 2009:113). Bu bağlamda bir mankurt; kim olduğunu, hangi soy ve kabileden geldiğini, anasını, babasını, çocukluğunu bilmez hale gelir. Hatta insan olduğunun dahi farkında olmaz. Aytmatov'a göre bir insanın hafizasını silme ve bilincini kökünden yok etme, o insanın kafasının uçurulacağı ya da bir yerinin kesileceği korkusundan çok daha ağır bir durumdur (Aytmatov, 2014e:149). Zira bilinci herhangi bir şekilde parçalanmış ya da silinmiş olan kişiler kendilerine ve tüm evrene karşı düşman bir varlık haline dönüşür (Korkmaz, 2009b:102). Örneğin Nayman Ana, hafızasından ve kimliğinden uzaklaştırılarak mankurt haline gelen oğlu Colaman tarafindan öldürülür (Jeziorska, 1991:55).

“Gün Olur Asra Bedel” adlı romanında Aytmatov hafıza, gelenek ve inançla iletişimi kesmenin sakıncalarına değinir. Modern insanın kendi kişiliği, aklı ve potansiyeline ne şekilde zarar verdiğini anlatır. Ona göre geçmiş ve geleceğini kaybederek belirsizlikte kalan insanoğlu sonunda yok olma tehlikesiyle karş1 karşıya kalacaktır. (Jeziorska, 1991:52-53). Aytmatov'un ilgili eserinde kendine, dünyaya/doğaya ve çevreye yabancılaşmak suretiyle ötekileşen bireylerle bunun tam aksine kendilik bilincine sahip olan, varoluşsal anlamdaki seçim ve sorumluluklarının farkında olan bireylere yer verilir (Deveci, 2009:258). Örneğin Sabitcan adlı karakter, kendi özüne ve değerlerine tamamen yabancılaşmış olmayı Abutalip ise öz değerlerine sımsıkı sarılarak otantik bir varoluşa sahip olmayı temsil eder.

Sabitcan, insanın bütün davranışları, düşünceleri, istekleri ve her işinin önceden tespit edileceğini iddia eder. Ona göre insan sadece merkezden verilen programa göre hareket edebilecektir (Aytmatov, 2014e:48). Sabitcan'ın insanın özgünlük ve özgürlügünü hiçe sayan bu tutumu onu modern mankurt haline getirmektedir. Onun kafasına yüzlerce yıl önce Juanjuanlar'ın Colaman'a yaptığı gibi deveboynu derisi geçirilmemişse de çok daha etkileyici bir sistemle, ideolojik şartlanma yoluyla bilinci ve bireysel varoluş çizgisinin rotası değiştirilmiştir (Eronat, 2009:264). Bu bağlamda Sabitcan, kendisini dış dünyaya bağlayan değerlerden koparak benliğini algılayamayacak noktaya gelmiştir. Zira benliğini rejime bağlayan Sabitcan, hem özgürlüğünü hem de benliğini kaybetmek suretiyle sıradan bir varoluş içerisinde kalmaya mahkum olmuştur (Deveci, 2009:250). Diğer bir ifadeyle Sabitcan ve onun gibi düşünen modern mankurtlar varoluşun anlamını kaybetmiş silik benliklerdir.

\footnotetext{
${ }^{4}$ Otantik varoluş hakkında geniş bilgi için bkz. Macquarrie, Existentialism, Pelican Books, New York 1973, ss.161-172.
} 
Abutalip, Sabitcan'ın tam aksine bütün gücünü kendilik bilincinden alır (Deveci, 2009:256). $\mathrm{O}$, sadece anı yaşayan ve duyumsayan biri olmayıp binlerce yıllık geçmişin bütün seziş ve kavrayışıyla var olan bir bendir. Abutalip, yabancılaşmanın ne gibi tehlikelere yol açacağının farkında olduğu için öze dönüşün kaçınılmaz olduğuna inanır. Zira insanlar ancak öze dönüş sayesinde çözülüp dağılmaktan, anlamsız ve değersiz hale gelmekten kurtulabilir (Eliuz, 2009:273). Bu bağlamda Abutalip türkü, efsane ve destanları yazıya geçirip geleceğe aktarmak suretiyle rejim tarafından yok edilmeye çalışılan benlikleri korumayı amaçlar (Deveci, 2009:256).

Aytmatov, "Dağlar Devrildiğinde Ebedi Nişanlı" adlı eserinde Arsen Samançin karakteri üzerinden "Yıldırım Sesli Manasçı" adlı öyküde ise Eleman karakteri üzerinden yabancılaşmanın tehlikelerine dikkat çeker. Arsen Samançin kendinden nefret edecek kadar kendinden uzaklaşmıştır. Zira onun benliği kitle kültürü tarafindan ezilmiştir (Aytmatov, 2007:84). Arsen Samançin kendisine yabancılaşmış olmanın verdiği öfke ve endişeyle ne yapacağını bilemez. (Aytmatov, 2007:41-42). Yıldırım Sesli Manasçı, Eleman'ın korkunç işkenceler altında öldürülmesi esasında Manas'ın öldürülmesi demektir. Böylelikle toplumu kendi özünden uzaklaştırıp dayanma ve tutunma dayanaklarını kırarak insanların atalar ruhundan yararlanmaları engellenir. $\mathrm{Bu}$ yolla kendi benliğinden kopmuş, özgüveni olmayan kimliksiz ve kişiliksiz kuşaklar ortaya çıkarma hedeflenir (Durmuş, 2009:217). Yukarıda ele alınan hususlardan hareketle Aytmatov'un özelde Kırgız halkına genelde ise bütün insanlığa özünü kaybetmemesi, ötekileşmemesi, köleleşmemesi kısaca mankurtlaşmaması için seslendiğini söyleyebiliriz (Söylemez, 2010a:10-11).

\section{Savaş}

Savaş, insanın varoluşunu derinden etkileyen unsurlardan biridir. İnsanın yok olma tehlikesini yoğun şekilde hissettiği savaş dönemleri esasında varoluşun acı gerçekleriyle yüz yüze gelmek demektir. Cengiz Aytmatov insan benliğini kuşatan savaş gerçeğiyle erken yaşlarda yüzleşmek durumunda kalmıştır. Bu bağlamda onun düşünce dünyasının şekillenmesinde ve varoluşa dair ileri sürdüğü görüşlerinde savaş temasının önemli bir yere sahip olduğu rahatlıkla ifade edilebilir.

Aytmatov için "savaştan önce", "savaştan sonra", "savaş boyunca" ifadeleri çok anlamlıdır. Ona göre bu ifadeler basit bir kronolojiden çok daha önemlidir. Çünkü bu kelimeler Aytmatov'a hayatın zorluklarını öğretmiştir. Sonuç olarak savaş, 20. yüzyılda bir dönüm noktası olarak insanlığın gelişimini savaş öncesi ve savaş sonrası olarak ikiye böldü. Her birey üzerinde ciddi anlamda etkileri olan savaş insanların hayatından hep en fazlasını istemiştir (Aitmatov, 1988:31).

Cengiz Aytmatov, insanlığ 1 derinden etkilemiş olan II. Dünya Savaşı'na ve savaşın her şeyi mahveden dehşetine tanık olan biri olarak eserlerinde savaş ve savaş sonrası yaşananlara değinir. Savaşın yıkan ve yok eden görünümünü insanların gözleri önüne sermeyi amaçlar. Savaş, insanları hayal dahi edemeyecekleri acıları çekmeye, tahammül edilmesi mümkün olmayan durumlarla karş1 karlıya kalmaya zorlar. Hayatının en önemli yıllarını bu acılarla geçirmek zorunda kalan Aytmatov, yaşanmışlıklarını eserlerinde işler. Savaşın insana ve tabiata verdiği zararları ele alır (Aylanç, 2010:51-52).

İkinci dünya savaşı Cengiz Aytmatov’un yaşam öyküsündeki temel dönüm noktalarından birisi olarak karşımıza çıkar. Henüz on üç yaşındayken cephe gerisi hizmetleri yürüten köy Sovyeti'nin kâtibi olan Aytmatov, evladını veya eşini yitirmiş, aç, susuz, çaresiz durumdaki insanların yüzüne yansıyan acıya bizzat şahit olarak büyür. Bu trajik durumlar onun ruhunda derin yankılar uyandırır (Korkmaz, 2009a:15). Bu bağlamda onun savaşa karşıt bir tutuma sahip olmasının yazarlık serüveninde önemli bir yer teşkil ettiği görülür (Kolcu, 2008:115). O "Fujiyama" adlı eserinde savaşın insan soyunun can düşmanı olduğunu vurgular (Aytmatov, 2017a:63). Aytmatov "Toprak Ana" adlı romanında ise savaşın kanlı çizmeleriyle insanları kırk yıl boyunca acımasızca çiğneyip ezebileceğini, masum insanları öldürebileceğini, her şeyi yıkıp kül edebileceğini lakin insan 
denen varlığa asla baş eğdiremeyeceğini, değerini düşürüp onu gerçek anlamda mağlup edemeyeceğini belirtir (Aytmatov, 2014g:102).

Aytmatov, sanatın gerçeği ile hayatın gerçeğini varoluşsal bir bakış açısıyla aynı potada eritmeyi başarabilmiş bir yazardır. Eserlerinde yer alan kahramanlar çoğu zaman karşılaştıkları durumlara anlam verememe problemiyle yüz yüze gelir. Örneğin "Toprak Ana" adlı eserde yer alan Tolganay, kocasının ve üç oğlunun ölümüne neden olan savaşa bir türlü anlam veremez. Savaş, babasızlık, anasızlık, dulluk, evlatsızlık, açlık, sefalet vb. her şey insana rağmendir. Her şey insanın aleyhine işlemektedir. İnsan yok sayllıp görmezden gelinmektedir (Kolcu, 1997:122-123). Buraya kadar ele alınan hususlardan hareketle sonuç olarak ifade etmek gerekirse Aytmatov, savaşın karşısında barışın, zulmün karşısında adaletin yılmaz savunucusu olan bir düşünürdür (Kala, 2019:31).

\section{Baba Figürü}

Cengiz Aytmatov'un hayata ve varoluşa bakışını etkileyen en önemli unsurlardan birisi kaybedilmiş baba figürüdür. Babasına olan hasreti hiçbir zaman dinmeyen Aytmatov'un gönlünde babasız olmaktan kaynaklı derin boşluk asla kapanmamıştır. Onun tebessümün de dahi bu derin hüznü görmek mümkündür.

Aytmatov, dokuz yaşında bir çocukken babasını kaybeder. Bu kayıp sıradan bir ölüm ya da bilinen bir kayıp olmayıp onun hayatının her anını saran ve sürekli yaşanan bir trajedidir (Buran, 2009:31). O, babasının toplum içinde aşağılanması için yapılan tüm zorlamalara karşı annesinin sürekli olarak "başınızı dik tutun" uyarılarını göz önünde bulundurarak hayata direnç gösterir (Korkmaz, 2016:66-67). Cengiz Aytmatov'un babası Törekul Aytmatov; özlenen, hep yolu gözlenen ve bir gün mutlaka döneceğine inanılan bir babadır. Kayıp baba figürü onun ruh ve duygu dünyasında o denli büyümüştür ki Aytmatov için babasının yokluğu varlığından daha etkili hale gelmiştir. Onun hayatı boyunca istediği tek şey, babasıyla buluşmak ve onu dünya gözüyle bir kez olsun görebilmektir (Buran, 2009:33).

Kayıp baba figürü, baba ve anne için çocukların önemi gibi varoluşsal temalar Aytmatov’un eserlerinde yoğun bir şekilde kendini hissettirir. "Cengiz Han'a Küsen Bulut" isimli öyküde Abutalip'in haksız yere evlatlarından ayrılarak mahkûm edilmesi ve evlatların babalarına duyduğu bitmek bilmeyen özlemin gerisinde Aytmatov'un babasının yokluğundan kaynaklanan acılarını görmek mümkündür.

Abutalip için çocukları varoluşunun en büyük amacı ve asıl nedenidir. O, çocukların varlı̆̆ının insan için en büyük mutluluk kaynağ 1 , onlarsız kalma ve onlardan kopmanın ise en büyük felaket olduğu inancındadır. Haksız yere tutuklanan Abutalip eşi ve çocukları için o denli kayg1 duyup acı çeker ki bu hal onun bütün benliğini kuşatır (Aytmatov, 2014c:8-10). Abutalip'in çocuklarının benliklerini ise baba hasreti kuşatır. Demiryolu kenarında durup hep babalarının dönüşünü beklerler. Babalarını beklemek onlar için hayatlarının aslı, başta gelen amacı olur. Konuşmaları, oyunları ve günlük hayatın bütün hareketlerinde hep babaları ve babalarının dönüşü vardır (Aytmatov, 2014e:272). Abutalip'in öldüğ̈̈ haberini alan komşusu Yedigey, onun çocuklarından ayrı kalmaya yüreğinin dayanmadığını vurgular. Ona göre ayrılık acısı korkunç bir şeydir. Hem çocuklar hem de babaları bu acıdan perişan olmuştur. Savaş dahil birçok sıkıntıyla hayatı boyunca mücadele etmiş olan Abutalip'in en değerli varlıkları olan evlatlarından ayrı kalmaya yüreği dayanamamıştır (Aytmatov, 2014e:257-258). "Oğulla Buluşma" adlı öyküde yer alan Cordon ise oğlunun öldüğüne bir türlü kendini inandıramaz. Oğluna duyduğu özlem ve hasret duygusu ruhunun derinliklerinde küllerin altında yer alan köz gibi hep canlı durmaktadır. Uzun yıllar önce ölen oğlu için duyduğu üzüntü hiç bitmez (Aytmatov, 2014f:35-36). "Dişi Kurdun Rüyaları" adlı romanda yer alan Boston karakteri de eşine ve çocuğuna olan bağlılığı varlığının en büyük anlamı olarak görür. Ona göre karısına ve çocuğuna duyduğu sevgi bu dünyada sahip olunacak en büyük servettir (Aytmatov, 2014ç:375). "Deniz Kıyısında Koşan Ala Köpek” adlı öyküde yer alan Emrayin 
isimli karakter ise hayattaki en önemli amacının oğlunda kendini sürdürmek olduğunu düşünür (Aytmatov, 2013:179). Benzer şekilde "Beyaz Gemi”"deki çocuk babasını bulduğunda varoluşla ilgili bulmacayı çözeceğine inanır (Jeziorska, 1991:48).

Sonuç olarak diyebiliriz ki babalık, kardeşlik gibi tanrısal varoluş bağlarından herhangi bir nedenle koparılan insan, yaşam karşısında kendisini kimsesiz, güvensiz ve yapayalnız hisseder (Korkmaz, 2016:67). Aytmatov bu duygular içerisinde hayata hep dışlanmış ve aşağılanmış bir çocuğun penceresinden veya yufka yürekli bir aksakalın dürbününden bakmıştır. (Şonbaeva, 2009:53). O, yazma eylemi ile kendisiyle iletişime geçmek suretiyle yalnızlı̆ğından kurtulmuş ve varoluşsal anlamda özgür olmuştur (Deveci, 2009:256).

\section{8.İntihar}

Cengiz Aytmatov'un eserlerinde önce çıkan varoluşsal temalardan birisi de intihardır. Onun birçok roman ve hikayesinde kendi yaşamına son veren karakterler yer alır. Ancak bu intiharların gerekçeleri bilinenden çok farklıdır. Bu bağlamda varoluşun anlamına yönelik derin sorgulamalarda bulunan hikâye ve roman kahramanlarının hayatın anlamını yok etmekten ziyade hayata anlam yüklemek ve yok edilmeye çalışılan insani değerlere can vermek için canlarına kıydıkları söylenebilir.

Aytmatov'un anlatılarında feda edilen ya da bir bedel olarak ödenen her yaşam aslında insan soyunu kendi kaderi üzerinde daha derin düşünmeye sevk eden bir uyarı niteliği taşımaktadır. Zira insan evren için kendinin, kendisi için de evrenin hayati bir öneme sahip olduğunu anlamaya mecburdur (Korkmaz, 2016:185). Bu bağlamda Aytmatov anlatılarında, büyük insani dönüşümleri içeren ruh aydınlanmalarının, sürekli yaşamsal bir bedele karşılık geldiği görülür (Korkmaz, 2009b:101).

Aytmatov'un "Beyaz Gemi” adlı öyküsünde, sevgi ve özgüvenden yoksun bir şekilde annesiz ve babasız olarak büyüyen çocuk, kendini azgın akan ırmağa atarak intihar eder. Aslında bu intihar, özelde çocuklarından sevgilerini esirgeyen parçalanmış ailelerin sorumsuz ebeveynlerini; genelde ise, geleceğini umursamayacak kadar bencilleşerek özüne yabancılaşmış olan insan soyunu protesto etmeyi amaçlar (Korkmaz, 2016:183). Mümin Dede'nin Maral Ana’y1 öldürmesinden sonra dünyada tutunacak kimsesinin kalmadığını düşünen çocuğun kendini ırmağa bırakması çocuk masumiyetinin her geçen gün daha da duyarsız hale gelen insanlığımıza ve sayrılı dünya bilincimize bir tepkidir (Korkmaz, 2016:202). Benzer şekilde "Kassandra Damgası" adlı romanda daima terkedilmiş çocuk kimliği ile yaşayan Andrey Krılstov'un kendini uzayın boşluğuna bırakarak intihar etmesi hem "Beyaz Gemi" deki çocuğun protestosuna daha gerçekçi bir boyut kazandırır hem de bir varoluş sorununu, daha problematik bir biçimde sorgulamanın yolunu açar. Her iki karakterin de ortada bırakılmış olması onların ruh ve benliklerinde yaşayacakları krizin çekirdeğini oluşturur. $\mathrm{Bu}$ örneklerden de rahatlıkla anlaşılacağı üzere Aytmatov'un anlatılarında yer alan intihar olgusu, oldukça derin anlamlar ihtiva etmektedir. Her iki karakter de intiharlarıla özüne yabancılaşan insanlığ 1 kendi bedenlerini ortadan kaldırmak suretiyle protesto etmektedir (Korkmaz, 2009b:100101).

Aytmatov'un eserlerinde yer alan intihar olgusu daha önce de belirtildiği üzere derin ve yoğun anlamlar içermektedir. Diğer bir ifadeyle düşünürümüz intihara varoluşsal bir bakış açısıyla yaklaşmıştır. Örneğin "Beyaz Gemi" adlı öyküde, iyi, saf, güzel ve temiz olanı temsil eden küçük çocuğun ölümü aslında onun temsil ettiği bütün güzellikleri ölümsüzleştirmesi anlamına gelmektedir (Söylemez, 2010b:37). Çocuğun intiharı seçmiș olması bir son değildir. Esasında bu intiharla Aytmatov; insanda bulunması gerekli olan hasletleri korumanın, manevi ve ahlaki temeller üzerine kurulmuş bir dünya inşa etmenin ne denli hayati öneme sahip olduğunu tüm insanlığa anlatmak ister. Kısaca burada verilmek istenen asıl mesaj, insan olmanın idrakine varmak suretiyle insanı insan yapan bütün değerlere sahip çıkmaktır (Koçak, 2010:80). 
"Gün Olur Asra Bedel" romanında yer alan karakterlerden biri olan Abutalip'in intiharı ise insan olmanın idrakine varamamış kişilere, her türlü kötülük, iftira, adaletsizlik ve vicdansızlığa karş1 duran bir tepkidir (Koçak, 2010:84). "Kassandra Damgası" adlı romanda Uzay rahibi Filofey ve Futurolog Robert Bork'un intiharları da gerçeği kabullenmek istemeyen insanlara karşı bir tepkidir (Koçak, 2010:88) Filofey'in kendini uzay boşluğuna bırakarak intihar etmesi, iletişimsizliğin ne büyük sorunlara neden olduğunu simgeler. Zira modern çağda insanlar her ne kadar uzaya hükmediyor olsalar da dünyada hemcinsleri hatta kendi kardeşleriyle dahi aralarına uzaysal mesafeler koyabilmektedir. Diğer bir ifadeyle uzayı keşfettiğini düşünen insanoğlu gereksiz önyarg1, tabu ve komplekslerden kaynaklı nedenlerden ötürü kendi benliğinden uzaklaşmaktadır (Korkmaz, 2016:66).

Aytmatov'un "Kassandra Damgası" adlı eserde Kassandra embriyonlarıla ilgili vurguları da intiharın varoluşsal açıdan değerlendirilmesi noktasında çok dikkat çekicidir. Bu bağlamda eserde konu edilen "kassandra embriyonları" karar verme şanslarının olması durumunda hiç doğmamayı tercih edeceklerini çünkü hiç kimseye fazla acı vermeden yok olmak istediklerini belirtirler. Başka bir ifadeyle bu embriyonlar yaşam mücadelesi vermek istemezler (Aytmatov, 2017b:21-22). Kassandra embriyonlarının sayısının durmadan çoğaldığını düşünen Filofey’e göre bu durumun sebebi günlük yaşamın ahlaksızlığı ve uğursuzluğu hissinin dünya bilinç altında giderek artıyor olmasıdır (Aytmatov, 2017b:27). Futurolog Robert Bork ise kassandra embriyonlarını birer genetik nihilist olarak değerlendirir. Ona göre kassandra embriyonları var olmamayı tercih ederek kaderlerinin üvey anne muamelesine "hayır" demek istiyordu. (Aytmatov, 2017b:82-83). Sonuç olarak ifade etmek gerekirse Aytmatov'un eserlerinde yer alan intihar vakaların1; neslin devam1, hak ve özgürlük duygusu, dünyanın yok oluşu ve insanın kendine yabancılaşmasına tepki gibi unsurlar tetiklemektedir (Koçak, 2010:90).

\section{Kader}

Cengiz Aytmatov, kaderin değiştirilmesi ve önceden bilinmesi mümkün olmayan bir hakikat olduğuna inanır. Alın yazısı herkes için büyük bir sırdır. Ona göre kaderin sır olması dahi bir kaderdir. Her anıyla bir sır olan kader herkes için gizemini sonsuza dek korumaya devam edecektir. Kader insan aklının sınırlarını aşan Tanrısal bir bilgidir (Aytmatov, 2007:5).

Aytmatov, kaderin cilvelerinin önceden kestirilemeyeceğini, bunun ebediyen böyle olacağını ve bu duruma bir izah yapılamayacağını belirtir. (Aytmatov, 2007:12). Zira insan hayatını yönlendiren kanunların hesaba dayanan bir mantığı yoktur (Aytmatov, 2014ç:86). Bu bağlamda hayatın çekici yanının onun anlamını tam olarak bilemeyecek ya da anlayamayacak olmamızdan geldiği söylenebilir (Tokat, 2017:24).

Herkesin ne yaşayacağının Tanrı tarafindan yazıldığına inanan Aytmatov, kimsenin kaderinden kaçamayacağını düşünür. Ona göre kader, planda olanı ertelemez. İnsanların hiç beklemediği kesişmeler kaderin sırlı aynasında gerçek oluverir (Aytmatov, 2007:33). Aydınlık ve gölgenin yan yana olması gibi insanın kaderi de mutluluk ve acıyı beraberinde getirir. Bir yanda kıvanç, bir yanda kaygı vardır. Hayat denilen şey bundan ibarettir. (Aytmatov, 2014d:129).

Aytmatov'un roman ve hikayelerinde yer alan karakterler üzerinden de kadere yönelik düşüncelerini belirttiği görülür. Bu bağlamda "Dağlar Devrildiğinde / Ebedi Nişanlı" adlı eserinde benliğini ve varoluşunun anlamını sürekli olarak sorgulayan Arsen Samançin, kaderin mutluluklara hep bir bedel istediğini vurgular. Samançin'e göre insan doğduğundan itibaren hep çelişkilerle kundaklanmış olduğundan sürekli bocalamaktadır (Aytmatov, 2007:196). Düşünürümüz, "Deniz Kıyısında Koşan Ala Köpek" adlı hikâyede ise denizde yoğun sisin altında çaresiz bir halde kalan kişiler üzerinden kader hakkındaki düşüncelerini vurgular. Örneğin Kirisk'in babası Emrayin, kadere razı olunması gerektiğini çünkü kaderin değişmeyeceğini söyler (Aytmatov, 2013:140). Benzer şekilde ihtiyar Orhan Ata'da insanın kabul etse de etmese de kaderinden kaçamayacağını vurgular (Aytmatov, 2013:162). 
Aytmatov, "Diş̧i Kurdun Rüyaları" adlı eserinde ise Abdias adlı karakter üzerinden insanın bu hayatta var olmasının anlam ve değerini kader boyutunda sorgulamaya çalışır. Abdias, kaderin boş bir kelime olmadığına iyi ve kötü bütün olayları kaderin belirlediğine inanır (Aytmatov, 2014ç:67). Bununla birlikte Abdias, insanları en saf fikirleri, en asil özlemleri için sistemli bir şekilde cezalandıran trajik bir kaderin bulunduğundan habersizdir (Aytmatov, 2014ç: 95). "Gün Olur Asra Bedel" romanında Abutalip'in hanımı Zarife de hayatı kader boyutuyla sorgular. Hayatta her şeyin korkunç, karışık ve anlaşılmaz olduğunu düşünen Zarife'ye göre herkes kaderini yaşamaktadır. Çocuklarının kendisi için hem kurtuluş hem de kader olduğuna inanan Zarife, onlar olmasa bir an dahi düşünmeden kendini öldüreceğini söyler (Aytmatov, 2014e:268). Bu bağlamda Aytmatov, kaderin bazen insanın elini kolunu bağladığını vurgular (Aytmatov\&Şahanov, 2015:20). Yukarıdaki değerlendirmelerden de anlaşılacağı üzere düşünürümüz sürekli olarak kaderin insan için kaçınılmaz, anlaşılmaz ve aklı aşan bir gerçekliğe sahip olduğunu belirtmiştir. Onun kadere yönelik böyle bir bakış açısına sahip olmasının arka planında yatan en önemli etkenin bizatihi kendi hayatı olduğunu söylemek mümkündür. Aytmatov, zorluklarla geçen yaşam mücadelesinde bazen kaderine darılmış, bazen anlamlandıramadığı şeylere bilge bir yürekle susmayı tercih etmiş ancak varoluşunu anlamlı kılmak için elinden gelenin en iyisini yapma gayretinden vazgeçmemiştir.

\section{0. Çaresizlik}

Çaresizlik, insanın bu hayatta hissettiği en yoğun duygulardan biridir. Hüzünlü ve mücadeleyle geçen bir yaşam öyküsüne sahip olan Cengiz Aytmatov'un eserlerinde bu duygu önemli bir varoluşsal tema olarak karşımıza çıkar. "Toprak Ana" adlı eserde buğday tohumları hırsızlar tarafından çalınan ve bütün umutları tükenerek çaresiz kalan Tolgonay Teyze'nin gözünde her şey anlamsız hale gelir. Hayat anlamsızlaşır. Ölmeyi ister (Aytmatov, 2014g:88-89). "Sultan Murat" adlı öyküde ise Sultan Murat hayalleri paramparça olmuş, düşleri yıkılmış bir şekilde çaresizce büyük acılar içerisinde hıçkırıklara boğulur. Acı ve gözyaşı içerisinde, kardeşi Hacı Murat'a babaları savaştan döndüğünde onu birlikte karşılayacaklarına dair verdiği sözü tutamayacağı için kahrolur (Aytmatov, 2014b:205).

"Gün Olur Asra Bedel” adlı romanda çok büyük haksızlıklara uğrayan Abutalip Kuttubayev ise umutsuzluk ve acılar içinde kıvranarak insanların nasıl bu kadar acımasız olduklarını, bu denli birbirlerine nefret duyduklarını anlamlandıramaz. Onlara en ufak bir zararı dokunmadığı ve onları tanımadı $\breve{g} 1$ halde kendisine düşman gibi davranmalarını, işkence etmelerini kendisine bir türlü açıklayamaz (Aytmatov, 2014c:7). Aynı romanın öne çıkan karakterlerinden birisi olan Yedigey'de çaresizliği bütün benliğinde hisseder. Abutalip'in eşi Zarife'nin çocuklarını alıp gitmesi üzerine acıdan deliye dönen Yedigey, sevdiği kadından ve çoğu babanın sevemeyeceği kadar çok sevdiği çocuklardan ayrı hayatın anlamsız olduğunu düşünür. $\mathrm{O}$ karlara gömülü bir şekilde ölmek ister ve Tanrıya olan isyanını şu şekilde ifade eder:

Tanrı yok! Yok! Mademki o bile insan hayatı ile ilgilenmiyor, insanın derdinden anlamıyor, başkalarından ne beklersin! Yok işte! Tanrı yok! Sarı- Özek kırında, karanlıklar içinde ve yapayalnız, yüreği kan ağlarken, böyle isyan etmişti. O güne kadar hiç böyle sözler çıkmış değildi ağzından. Hatta, her zaman örnek aldığı Yelizarov, bir bilim adamı olarak Tanrı'nın olamayacağını söylediği zaman ona karşı çıkmış, inancından asla vazgeçmemişti. Ama işte bugün böyle isyan ediyor ve Tanrı'nın olmadığını bağıra bağıra söylüyordu (Aytmatov, 2014e:334).

"Elveda Gülsarı" adlı romanın kahramanı olan Tanabay, hayata dair her şeyi çaresizlik içerisinde sorgular. Bütün çalışma ve gayretine rağmen insanlar tarafından halk düşmanı olarak görülmesini kabullenemez (Aytmatov, 2014d:182). Öfkesi zamanla nefrete dönüşen Tanabay, çaresizlik içerisinde varoluşu sorgular. Bu bağlamda o kendi benliğinden, bütün hayatından ve her şeyden nefret eder. Gözünün gördüğü her şeyden tiksinir (Aytmatov, 2014d:151).

Cengiz Aytmatov, "Deniz Kıyısında Koşan Ala Köpek" adlı hikâyede yer alan Emrayin, Orhan Ata, Mılgın ve Kirisk adlı karakterlerin yaşadıkları çaresizliği de varoluşsal bir derinlikle 
ortaya koyar. Denizdeki sisin ortadan kalkması için Göktanrı'ya sürekli olarak dua etmelerine rağmen sisin dağılmaması onları çileden çıkartır (Aytmatov, 2013:146) ve isyan noktasına getirir. Bu bağlamda öyküde yer alan Mılgın adlı kişi çaresizlikten delirme noktasına gelir ve rüzgarların şamanı olarak nitelendirdiği güce ağza alınmayacak hakaretlerde bulunur. Küçücük bir çocuğun susuz kalmasına sebep olduğu için onu kalleşlikle suçlar (Aytmatov, 2013:154-155).

Nayman Ana'nın Juan-Juanlar tarafından işkenceyle hafizası silinmek suretiyle mankurt haline getirilen oğlu Colaman'a yaktığı ağıtta ise bir annenin hayatı, Tanrı'yı ve varoluşu ne denli yoğun bir çaresizlik içerisinde sorguladığına şahit oluruz:

Oy balam, oy! Can balam oy! Yeryüzüne hayat veren güneş, senin için kapkara bir yıldız oldu da bir damla 1şık vermedi! Ondan nefret etmedin mi Oy balam, oy! Can balam oy!. Acı çığlıkların bozkırda yankı yankı yayılanda, gece-gündüz Tengri! Deyip yana-yakıla gökyüzü boşluğuna seslendiğinde, dayanılmaz acılarla kıvrananda, kusmukların, pisliklerin, sidiklerin içinde boğulanda, balam oy, vücudun yıkılıp içine sinekler üşüşende, yavaş yavaş aklını kaybedip gittiğinde, hepimizi yaratıp sonra da kendi halimize salıveren Tengri'ye son gücünü toplayıp isyan etmedin mi? Oy balam, oy! Can balam oy! (Aytmatov, 2014e:150).

"Dişi Kurdun Rüyaları" adlı eserin önemli karakterlerinden biri olan Boston'da, dişi kurt Akbar'1 vurmak isterken kurtla birlikte kendi elleriyle küçük oğlu Kence'yi vurması üzerine gazabını kendisine yönelttiğini düşündüğü Tanrıya sitem eder (Aytmatov, 2014ç:396-397). Akbar'ın yavrularını çaldığı için felaketine sebep olan Bazarbay'ı öldüren Boston, tarifi mümkün olmayan acı ve çaresizlik içerisinde kahrolur. Bu bağlamda Boston, dünyanın sonunun geldiğini her zaman içinde yaşattığı küçük evrenin yok olup gittiğini düşünür. Kendi dünyasına yabancılaşıp başka biri olduğu ve evrenini kaybettiği için varoluşa yönelik derin bir sorgulama faaliyetine girer (Aytmatov, 2014ç:399-400).

Cengiz Aytmatov, yukarıda değinilen hususlarda bize insanın varoluşa ve hayata dair ne denli yoğun çaresizlikler içinde kalabileceğini, bu halin insanı Tanrı dahil her şeyin anlam ve gerçekliğini sorgulamaya iteceğini hem edebi hem de felsefî derinliği olan bir yaklaşımla göstermeyi başarmıştır. Ele aldığı konulara evrensel bir bilinçle yaklaşmayı prensip haline getirmiş olan Aytmatov, çaresizlik konusunda da dünya üzerinde yaşayan bütün insanların ortak acı ve 1stıraplarını varoluşçu bir bakış açısıyla ortaya koymaya çalışmıştır.

\section{Kötülük}

Cengiz Aytmatov, kötülük problemiyle alakalı dikkate değer görüşler ortaya koymuştur. Özellikle "Kassandra Damgası", "Dişi Kurdun Rüyaları" ve "Beyaz Gemi” adlı eserlerinde kötülük sorununa yoğun şekilde göndermelerde bulunur.

Aytmatov “Beyaz Gemi” adlı romanında özellikle Orozkul karakteri üzerinden kötülüğü ele alır. Orozkul, bencilliği ve kötülükleri içerisinde bilinç yitimine uğrayarak genç yaşında tükenmiştir. Kendi kötülüğü ve karamsarlığı onun tükenmesine neden olmuştur. Duygularını kontrol edemediği için içinde sürekli büyüyen öfkesi ve küçük hırsları Orozkul'un davranışlarını şekillendiren temel unsurlar olmuştur. Aslında o farkında olmadan asıl kötülüğü kendine yapmıştır. Zira ortak bilinç ve gelenekten kopmak suretiyle yeni bir hayat inşa edememiştir (Gariper\&Küçükcoşkun, 2009:181).

Orozkul, Tanrı'nın herkese düzinelerce çocuk verirken kendisine bir tane bile evlat vermemesini kabullenemez. Hiçbir iz bırakmadan bu dünyadan ayrılacağı düşüncesine tahammül edemeyen Orozkul, duygusal olarak çok kötü bir noktaya gelmek suretiyle öfkeden kudurur (Aytmatov, 2014a:25-26). Öfkesi o denli yoğundur ki kendisi dahil herkesin ölmesini ister. Orozkul her şeyin ters gittiği ve her şeyin kötü olduğu dünyanın yok olmasını ister (Aytmatov, 2014a:80). Aytmatov, insanın doğasında yer alan kötülüğe karşı durmayı amaçlar. Ona göre zafer hiçbir zaman Orozkul'un değildir. Her ne kadar romanın sonunda çocuk ölüyor olsa da ahlak üstünlügü çocukta kalmaktadır (Y1lmaz, 2015:44). 
"Beyaz Gemi” adlı romanın ana karakterlerinden biri olan Mümin Dede’nin eşi İhtiyar nine Bekey teyzeye darılırken çocuklarını ve eşini kaybetmesinin Allah'ın ona ceza vermesi olarak değerlendirir. Hatta neden böylesine kötü bir ortamın içerisinde yer aldığını aklı almadığı için "Günahım neydi beni bu hallere düşürdün Allah'ım!" diye şikayetlenir. (Aytmatov, 2014a:34-35). Mümin Dede ise gerçek hayatta mutluluğun yanı sıra, insanın peşini hiç bırakmayan, ruhunu ve bütün hayatını allak bullak eden felaket ve mutsuzluklar olduğunu iddia eder (Aytmatov, 2014a:96).

Cengiz Aytmatov, varoluşun ironisini gözler önüne serer "Beyaz Gemi” adlı romanında. Kötülüğün her ne kadar asli bir unsur olmadığını iddia etse de roman da yer alan ana karakterlerin hayatta karşı karşıya kaldıkları acı, sıkıntı ve olumsuzluklara dirençleri bir noktadan sonra yok olmaktadir.

Aytmatov, "Kassandra Damgası" adlı eserinde kötülük sorununa yönelik düşüncelerini, Futurolog (Robert Bork) ve Filofey (Andrey Kriltsov) isimli karakterler üzerinden izah etmeye çalışır. Futurolog (Robert Bork), hayatta her zaman iyiliğin az kötülüğün ise çok olduğunu iddia eder. Ona göre dünya şuuru çökme, kendi kendini yok etme diğer bir ifadeyle sonsuzluğa gömülme ve mahvolma tehlikesiyle karşı karşıyadır (Aytmatov, 2017b:56-57). Bork, tüm belaların insanlardan kaynaklandığını kimsenin anlamak istemediğini düşünür. Şuurlu yaratıklar olan insanların giderek kötüleşen hayat için sorumluluk üstlenmekten devamlı kaçındığını belirten fütürolog, herkesin üzerine düşeni yapmamak için bir sürü bahane ürettiğini, iyi ile kötüyü ayırt etmediğini ve sadece kendini kurtarmaya çalıştı̆ııı iddia eder (Aytmatov, 2017b:132-133).

Yeryüzündeki kötülüğün kaynağ1 sadece insanlardır fütüroloğa göre. Ama ne gariptir ki her insan kötülüğ̈̈n kendisi, kendi ailesi, nesli, milleti, devleti ve biraz daha ileri gidersek 1 rk1, dini, ideolojisi... kaynaklı olduğunu kabul etmez. Aksine kötülüğün kaynağını başka şeylere atfeder (Aytmatov, 2017b:133). Dünya şuurunun taşıyıcıları olan insanların uğursuz ihtiraslarının durmaksızın artmasına tahammül etmenin dayanılmaz bir hal aldığını vurgulayan Bork, içimizde, tabiatımızda ahlakın kırıldığı, çöktüğü ve tahrif olduğunu öne sürer (Aytmatov, 2017b:57). Ona göre teknolojik gücümüz arttıkça, hatalarımız, hayasızlığımız, günahlarımız da inanılmaz derecede artmaktadir (Aytmatov, 2017b:133).

Filofey (Andrey Kriltsov) ise iyilik ve kötülük enerjisinin insanlığa ezelden eşit şekilde verilen değerler olduğunu insanın medeniyetin zirvesine yükselmek için içindeki kötülüğü yenmesi gerektiğini vurgular (Aytmatov, 2017b:32). Filofey, bir anne adayının içinde bulunduğumuz çağda; açlık, hastalık, savaş, ekonomik kriz, sosyal patlama, cinayet, fuhuş, uyuşturucu, etnik çatışma, rrkçılık ve ekolojik felaket gibi düşünmeden edemeyeceği tehlikeler zincirinin olduğunu vurgular. Ona göre insanın neden olduğu felaketlerin ölçüsü sürekli olarak büyümektedir (Aytmatov, 2017b:40-41). Bu bağlamda Filofey, insanlığın içine düştügü bunalım ve kötülügün geldiği nokta karşısında dehşete kapılır. Tanrıya karşı çıkan, ceset tuzakları operasyonlarıyla ağlayarak babalarının cesedine koşan çocukları da bombayla parçalayan gözü dönmüş canilerin nereden geldiğini bir türlü anlayamaz (Aytmatov, 2017b:30).

Aytmatov, "Dişi Kurdun Rüyaları" adlı eserinde Petruha adlı karakter üzerinden her türlü kötülüğe neden olan unsurlara değinir. Petruha, sürekli olarak zengin olmak isteyen, durmaksızın kendini öven ve maymun gibi olur olmaz herşeyi taklit etmeye çalışan biridir. Aytmatov'a göre bu üç unsur kötü olan ne varsa, yüzyıllardan beri ve evrensel olarak zayıflara dayanak teşkil eden sütunlardır. $\mathrm{O}$, derinliği olmayan yapay fikirlerin, insanlığ 1 sarsan, yıkan dar görüşlerin hep bu unsurlardan kaynaklandığını iddia eder (Aytmatov, 2014ç:141). İnsanların kendi çıkarları, kendi hırsları, kendi kusur ve erdemlerine göre hareket ettiklerini belirten düşünür, (Aytmatov, 2014ç:40) insanoğlunun çıkarı uğruna yerküreyi bir limon gibi sıkabileceğini vurgular (Aytmatov, 2014ç:70).

Aytmatov, insanoğlunun kötülük sorunu karşısında bazı durumlarda çaresiz kaldığına inanır. Bu hususla ilgili olarak şunları söyler: "İnsanlar düşünen yaratıklar olarak ortaya çıkışlarından beri kendilerini daha iyi tanımaya çalışmışlar, ama bütün çabalarına rağmen şu soruya bir cevap 
verememişlerdi: Kötü, hemen hemen her defasında, niçin iyiden daha güçlü olarak ortaya çıkıyor?...” (Aytmatov, 2014ç:20).

Yukarıda ele alınan hususlar da göstermektedir ki Aytmatov hem "Beyaz Gemi" hem de "Kassandra Damgası" adlı eserlerinde insanın insana dünyayı zehir ettiği ve yaşanmaz kıldı̆̆ fikrini işlemektedir (Kolcu, 2015:303). Cengiz Aytmatov'un eserlerini ve fikirlerini ciddi anlamda tahlil etmiş olan Ramazan Korkmaz'ın da vurguladığı gibi bireysel anlamda işlenen suçların tamamı, evrensel bir tükeniş çizgisinde buluşmak suretiyle insanlığa karşı birleşik bir güç oluşturmakta ve kısa süre içerisinde silsilevi bir felaketler dizgesine dönüşebilmektedir (Korkmaz, 2016:165). Sonuç olarak ifade etmek gerekirse eserlerinde konu edindiği varoluşsal sorunlara evrensel bir bilinçle yaklaşabilmeyi başarmış olan Aytmatov, dünyanın herhangi bir noktasında işlenen her suç, her kötülügün hepimizi ilgilendirdiğini vurgular. Ona göre herhangi bir kötülüğün işlendiğini bilmesek ve çok uzağında olsak bile bu gerçek değişmez (Aytmatov, 2014ç:247).

\section{Sonuç}

Din felsefesi felsefe ve din, etik, estetik, edebiyat gibi sahalar arasında köprüler kurabilme ve varoluşumuzu ilgilendiren hemen her konuyu kendisine problem edinebilme potansiyeline sahip bir bilim dalıdır. Bu çalışmada genelde felsefe-edebiyat, özelde ise varoluşçu din felsefesi ile Cengiz Aytmatov'un edebi eserleri arasındaki ilişki incelenip buradan hareketle insanı, alemi ve varoluşu anlamlandırma noktasında felsefe ve edebiyatın ortak kaygılara sahip oldukları sonucuna varılmıştır. Zira her iki alan da temelde insana ve varoluşa dair hususları kendilerine özgü bir yöntemle izah etmeyi amaçlamaktadır.

Bu çalışmada çağdaş Türk düşüncesinin önemli simalarından birisi olan Kırgız yazar Cengiz Aytmatov'un edebî eserlerinde konu edindiği; insan, Tanrı, tabiat, özgürlük, yabancılaşma, savaş, baba figürü, intihar, çaresizlik, kader ve kötülük gibi problemler ile varoluşsal din felsefesinde konu edinilen problemlerin birbirine çok yakın olduğu tespit edilmiştir. Bu bağlamda Aytmatov'un eserlerinde varoluşsal temaların felsefi olarak adlandırılabilecek bir derinlikte işlendiği görülmüştür.

Cengiz Aytmatov sadece bir yazar olmanın ötesinde bilge bir kişiliktir. O varoluşun ironisi ve dinamizmini benliğinde içselleştirmeyi başarmıştır. Bunun en somut örneği ise eserlerinde ele aldığı konuların taşıdı ğı varoluşsal derinliktir. Bu bağlamda yazar insanı edebiyatın merkezine almış, Tanrı'yı yeryüzünde yaşayan bütün insanların ibadet ettiği kutsal varlık olarak görmüş, tabiatı ve doğada yaşayan canlıları bambaşka bir derinlikte tahlil etmiş, özgürlügün insanı insan yapan ana unsur olduğunu vurgulamış, benliğine yabancılaştırılıp mankurt haline getirilen kişilerin insan olma onurunu kaybettiğine değinmiş, savaşın insan ruhunda açtığı onulmaz yaraların mahiyetinden bizleri haberdar etmiş, kayıp babanın insanın benliğinde boşluğu doldurulmaz sürekli kanayan bir yara olduğunu gözler önüne sermiş, intiharın yok olmaktan ziyade kötülüklere isyan edip hakiki anlamda var olmayı temsil ettiğini göstermiş, çaresizlik hissinin insanı ne hallere düşüreceğini belirtmiş, kaderden kaçınmanın mümkün olmadığını vurgulamış ve insanların yaptıkları kötülüklerden dolayı alemi yaşanılmaz bir yer haline getirdiklerini iddia etmiştir.

Sonuç olarak Cengiz Aytmatov’un eserlerinde konu edindiği hususlan evrensel bir bilinçle ele almaya çalıştığı söylenebilir. Bu bağlamda o; insana, aleme ve alemde yer alan bütün varlıklara bir bilge ruhuyla yaklaşmıştır. Aytmatov'un insana, tabiata kısacası var olan her şeye çok derin bir sevgisi vardır. O hayatı boyunca varoluşun anlam ve derinliğini yakalama çabasında olmuştur. Çalışmamız süresince dile getirmeye çalıştığımız bu ve buna benzer özellikleri onun eserleri ve düşüncelerinin varoluşçu din felsefesi çerçevesinde ele alınmasına dair vurgumuzu haklı çıkarmaktadır. 


\section{Kaynakça}

Aitmatov, C. (1988). The Time to Speak Out, (Trans. Paula Garb), Progress Publishers.

Akmataliyev, A. (1998). Cengiz Aytmatov'un Dünyası, Atatürk Kültür Merkezi Başkanlığı Yayınları.

Alpyă̆ı1l, R. (2014). Türkiye'de Otantik Felsefe Yapabilmenin İmkânı ve Din Felsefesi Paul Ricoeur Örneği Üzerinden Bir Soruşturma, İz Yayınc1lık.

Alpyağıll, R. (2016). Kıta Avrupası Din Felsefesi ve Mistik Gelenekler -Kesişen Yollar-, İz Yayıncilik.

Asanova, U. (2008). Cengiz Aytmatov'un Eserlerinde Kültür Bunalımının Felsefesi, (Çev. Lilia Alkaya), Türk Edebiyatı Aylık Fikir ve Sanat Dergisi, 54-58.

Aydın, M. S. (1999). Din Felsefesi, İzmir İlahiyat Fakültesi Vakfi Yayınları.

Aylanç, M. (2010). Cengiz Aytmatov'un Öykü ve Romanlarında Savaş ve Savaş Karşıtllı̆ğ, (Editör Orhan Söylemez), Cengiz Aytmatov: Tematik İncelemeler içinde, Atatürk Kültür Merkezi Yayın1, 49-70.

Aytmatov, C. (2007). Dă̆lar Devrildiğinde Ebedi Nişanll, (Çev. Güzel Sarıül Şonbaeva), Ufuk Kitap.

Aytmatov, C. (2013). Yıldırım Sesli Manascı, Yüzyüze, Deniz Klyısında Koşan Ala Köpek (Hikâyeler), (Çev. Refik Özdek), Ötüken Neşriyat.

Aytmatov, C. (2014a). Beyaz Gemi, (Çev. Refik Özdek), Ötüken Neşriyat.

Aytmatov, C. (2014b). Cemile-Sultan Murat (Hikâyeler), (Çev. Refik Özdek), Ötüken Neşriyat.

Aytmatov, C. (2014c). Cengiz Han'a Küsen Bulut, (Çev. Refik Özdek), Ötüken Neşriyat.

Aytmatov, C. (2014ç). Dişi Kurdun Rüyaları, (Çev. Refik Özdek), Ötüken Neşriyat.

Aytmatov, C. (2014d). Elveda Gülsarı, (Çev. Refik Özdek), Ötüken Neşriyat.

Aytmatov, C. (2014e). Gün Olur Asra Bedel, (Çev. Refik Özdek), Ötüken Neşriyat.

Aytmatov, C. (2014f). Kızıl Elma, Oğulla Buluşma, Beyaz Yağmur, Asker Çocuğu, Deve Gözü (Hikâyeler), (Çev. Refik Özdek), Ötüken Neşriyat.

Aytmatov, C. (2014g). Toprak Ana, (Çev. Refik Özdek), Ötüken Neşriyat.

Aytmatov C. \& Şahanov M. (2015). Şafak Sancısı Yüzyılların Kavşağındaki Muhabbet, (Çev. Damira İbragim), Bengü Yayınlar1.

Aytmatov, C. (2017a). Fuji-Yama, (Çev. Mehmet Özgül), Nora Kitap.

Aytmatov, C. (2017b). Kassandra Damgasl, (Çev. Ahmet Pirverdioğlu), Nora Kitap.

Buran, A. (2009). Repressiya ve Aytmatov, (Editör Ramazan Korkmaz), Cengiz Aytmatov içinde, Kültür ve Turizm Bakanlığı Yayınları, 29-35.

Cevizci, A. (2005). Paradigma Felsefe Sözlüğü, "Varoluşçuluk”, Paradigma Yayıncılık, 1695-1696.

Deveci, M. (2009). Gün Olur Asra Bedel Romanında Özgürlük Sorunu, (Editör Ramazan Korkmaz), Cengiz Aytmatov içinde, Kültür ve Turizm Bakanlığı Yayınları, 247-259.

Durmuş, M. (2009). Yıldırım Sesli Manasçı'da Anlatı Kahramanının “Mitik Sese” Dönüşümü, (Editör Ramazan Korkmaz), Cengiz Aytmatov içinde, Kültür ve Turizm Bakanlığı Yayınları, 209-221. 
Eliuz, Ü. (2009). Cengiz Han'a Küsen Bulut Romanında Simgesel Söylem, (Editör Ramazan Korkmaz), Cengiz Aytmatov içinde, Kültür ve Turizm Bakanlığı Yayınları, 271-281.

Erbay, N. K. (2002). Cengiz Aytmatov'un Eserlerinde Tabiat, Kültür Bakanlığı Yayınları.

Eronat, K. (2009). Gün Uzar Yüzyıl Olur Romanında Mitik ve Modern Mankurtlar, (Editör Ramazan Korkmaz), Cengiz Aytmatov içinde, Kültür ve Turizm Bakanlığı Yayınları, 261-269.

Ertürk, R. (2012). Varoluşsal Din Felsefesine Giriş, Yarın Yayınları.

Flew, A. (1979). A Dictionary of Philosophy, Palgrave Macmillan.

Gariper, C. \& Küçükcoşkun, Y. (2009). Beyaz Gemi'de Tükenişs ve Yeniden Doğuş, (Ramazan Korkmaz), Cengiz Aytmatov içinde, Kültür ve Turizm Bakanlığ1 Yayınları, 177-187.

Gökçek, F. (2004). Cengiz Aytmatov'un Romanlarında Din Teması ve "Dişi Kurdun Rüyaları", Cengiz Aytmatov Doğumunun 75. Y11 İçin Armağan içinde, Kırgızistan-Türkiye Manas Üniversitesi Yayınları, 93-107.

Guignon, C. B. (2000). Existentialism, Concise Routledge Encyclopedia of Philosophy, Routledge, 265.

Gündoğan, A. O. (2014a). Sunuş, (Editörler Mustafa Günay \& Ali Osman Gündoğan), Felsefe ve Edebiyat içinde, Çizgi Kitabevi, 7-8.

Gündoğan, A. O. (2014b). Edebiyat İle Felsefe İlişkisi Üzerine, (Editörler Mustafa Günay \& Ali Osman Gündoğan), Felsefe ve Edebiyat içinde, Çizgi Kitabevi, 51-62.

Gündoğan, A. O. (2014c). Felsefe ile Edebiyat Illişkisi Üzerine / Vefa Taşdelen’in Ali Osman Gündoğan ile Yaptığ Röportaj, Röportajı yapan Vefa Taşdelen, (Editörler Mustafa Günay \& Ali Osman Gündoğan), Felsefe ve Edebiyat içinde, Çizgi Kitabevi, 63-72.

Gürsoy, K. (2013). Birleyerek Oluşmak / Felsefe ve Tasavvuf Üzerine Konuşmalar, Aktif Düşünce Yayınları.

Gürsoy, K. (2014a). Varoluş ve Felsefe, Aktif Düşünce Yayınc1lık.

Gürsoy, K. (2014b). Felsefe-Edebiyat Ilisskilerini Anlamak, (Editörler Mustafa Günay \& Ali Osman Gündoğan), Felsefe ve Edebiyat içinde, Çizgi Kitabevi, 41-49.

Güney, M. (2014). Edebiyatın Iç̧indeki Felsefe, (Editörler Mustafa Günay \& Ali Osman Gündoğan), Felsefe ve Edebiyat içinde, Çizgi Kitabevi, 265-268.

Güven, F. (2014) Felsefe, Edebiyat, Özne, (Editörler Mustafa Günay \& Ali Osman Gündoğan), Felsefe ve Edebiyat içinde, Çizgi Kitabevi, 171-182.

Işık, A. (2016). Din ve Sanat İlişkisi, (Editörler Recep Kılıç \& Mehmet Sait Reçber), Din Felsefesi El Kitab1, Grafiker Yayınlar1, 391-420.

İnam, A. (2014). Coğrafya Kavramı Odağında Felsefe ve Edebiyat, (Editörler Mustafa Günay \& Ali Osman Gündoğan), Felsefe ve Edebiyat içinde, Çizgi Kitabevi, 157-170.

İnam, A. (2009). Yaşamla Yoğrulmuş Bilgi, Say Yayınları.

İyi, S. (2014). Edebiyatın İçi Felsefenin Dışı, (Editörler Mustafa Günay, Ali Osman Gündoğan), Felsefe ve Edebiyat içinde, Çizgi Kitabevi, 143-156.

Jezıorska, I. (1991). Religious themes in the novels of Chingiz Aitmatov, Cultural Change and Continuity in Central Asia. (Ed. Shirin Akiner), England: Kegan Paul International Ltd., 4570 . 
Kala, M. E. (2019). Cengiz Aytmatov'un Düşünce ve Sanatında Ahlaki Zemin ve Etkileme Biçimleri, Tyb Akademi, 21-33.

Kanter, M. F. (2009). Kendini Tüketen Bireylerin Öyküsü: Kassandra Damgasl, (Editör Ramazan Korkmaz), Cengiz Aytmatov, Kültür ve Turizm Bakanlığı Yayınları, 311-315.

Kazımoğlu, S. (1994). Cengiz Aytmatov ve Dünya Edebiyatı, (Haz. Cengiz Ertem), Littera Edebiyat Yazıları, Littera Yayın, Cilt: 5, 26-34.

Koç, T. (2013). Varoluşun Tanıkları, Hece Yayınları.

Koç, E. (2015). Felsefe ve Edebiyat, Kırıkkale Üniversitesi Sosyal Bilimler Dergisi, Ocak 2015, Cilt: 5, Say1:1, 105-117.

Koç, E. (2018). Varoluşçuluğun Türkiye'deki İlk Etkileri, Sosyal Bilimler Dergisi, 794-816.

Koçak, M. (2010). Cengiz Aytmatov'un Eserlerinde İtihar, (Editör Orhan Söylemez), Cengiz Aytmatov: Tematik İncelemeler içinde, Atatürk Kültür Merkezi Yayını, 71-90.

Kolcu, A. İ. (1997). Milli Romantizm Açısından Cengiz Aytmatov, Ötüken Neşriyat.

Kolcu, A. İ. (2015). Bozkırdaki Bilge Cengiz Aytmatov, Salkımsöğüt Yayınevi.

Kolcu, A. İ. (2008). Cengiz Aytmatov Üzerine Yazllar, Salkımsögüt Yayınları.

Korkmaz, R. (2009a). Suların Sırrını Ödünçleyen İnsan: Aytmatov, (Editör Ramazan Korkmaz) Cengiz Aytmatov içinde, Kültür ve Turizm Bakanlığı Yayınları, 13-19.

Korkmaz, R. (2009b). Evrenin Bilinci: İnsana Dönüs İzleği, (Editör Ramazan Korkmaz) Cengiz Aytmatov, Kültür ve Turizm Bakanlığı Yayınları, 93-103.

Korkmaz, R. (2016). Aytmatov Anlatılarında Ötekileşme Sorunu ve Dönüş İzlekleri, Kesit Yayınları.

Maclntyre, A. (1967). "Existentialism”, (Ed. Paul Edwards), The Encyclopedia of Philosophy, Vol. 3, London: Collier-Macmillan Ltd., 147-154.

Macquairre, J. (1973). Existentialism, Pelican Books.

Magill, F. (1992). Egzistansiyalist Felsefenin Beş Klasiği, (Çev. Vahap Mutal), Dergâh Yayınları.

Mignon, L. (2009). Cengiz Aytmatov: Toprağın Türküsünden Toprakların Türküsüne, (Editör Ramazan Korkmaz) Cengiz Aytmatov içinde, Kültür ve Turizm Bakanlığı Yayınları, 105113.

Murdoch, I. (2015). Edebiyatta ve Felsefede Varoluşçular ve Mistikler, (Çev. Süha Sertabiboğlu), Ayrıntı Yayınları.

Oğuz, G. (2008). Kassandra Damgası, Türk Edebiyatı Aylık Fikir ve Sanat Dergisi, 82-84.

Oymak, A. (2010). Aytmatov'un Romanlarında Sistem Eleştirisi, (Editör Orhan Söylemez) Cengiz Aytmatov: Tematik İncelemeler içinde, Atatürk Kültür Merkezi Yayını, 161-167.

Özer, K. (1976). Cengiz Aytmatov'a Göre Edebiyatın Görevi İnsanın Yetilerini Geliştirmektir, Nesin Edebiyat Vakfi Yılliğı 1976, ss.413-415.

Reese, W. L. (1980). Dictionary of Philosophy and Religion Eastern and Western Thought, Humanities Press.

Sarı, A. (2016). Felsefe Edebiyata Kendini Nasıl Eklemler?, Çizgi Kitabevi.

Söylemez, O. (2010a). Cengiz Aytmatov'un Ardindan: Ata-Beyit'ten Ana-Beyit'e, (Editör Orhan Söylemez) Cengiz Aytmatov: Tematik İncelemeler içinde, Atatürk Kültür Merkezi Yayını, 7-14. 
Söylemez, O. (2010b). Orhan Söylemez İle Cengiz Aytmatov Üzerine, (Editör Orhan Söylemez) Söyleşiyi Yapan: Seval Koçoğlu. Cengiz Aytmatov: Tematik İncelemeler içinde, Atatürk Kültür Merkezi Yayını, 35-45.

Şakiyeva, Ç. A. (2009). Cengiz Aytmatov ve Modern Psikoloji, (Editör Ramazan Korkmaz), (Çev. Lilia Alkaya), Cengiz Aytmatov içinde, Ed., Kültür ve Turizm Bakanlığı Yayınları, 137-141.

Şonbaeva, G. S. (2009). Sesinin İçinde Ak Bir Güvercin İdim, (Editör Ramazan Korkmaz) Cengiz Aytmatov içinde, Kültür ve Turizm Bakanlığı Yayınları, 53-59.

Taliaferro C. \& Marty E. J. Ed. (2010). A Dictionary of Philosophy of Religion, Continuum Publishing.

Taşdelen, V. (2013). Felsefeden Edebiyata, Hece Yayınları.

Taşdelen, V. (2014). Metafizik ve Edebiyat: Metafizik Sorundan Metafizik Gerçeğe, (Editörler Mustafa Günay, Ali Osman Gündoğan), Felsefe ve Edebiyat içinde, Çizgi Kitabevi, 183210.

Taşdelen, V. (2015). Felsefe Kültürü, Hece Yayınları.

Taşdelen, D. K. (2014). Dilthey'in Insani/Tinsel Dünyada Shakespeare’i Konumlandırması ve Unutulan Tarihselliği Oluşturma Çabasına Bir Örnek Olarak Macbeth, (Editörler Mustafa Günay, Ali Osman Gündoğan), Felsefe ve Edebiyat içinde, Çizgi Kitabevi, 431-449.

Timuçin, A. (2014). Felsefesiz Edebiyat Edebiyatsız Felsefe Olur mu ya da Olmalı mı?, (Editörler Mustafa Günay, Ali Osman Gündoğan), Felsefe ve Edebiyat içinde, Çizgi Kitabevi, 31-40.

Tokat, L. (2013a). Varoluşçu Teoloji, Elis Yayınları.

Tokat, L. (2013b). Metafizik Belirsizlik ve Anlam Sorunu Açısından Din ve Felsefe, Dinbilimleri Akademik Araştırma Dergisi, Cilt 13, Sayı 1, 7-25.

Tokat, L. (2017). Anlam Sorunu, Elis Yayınları.

Tokat, L. (2018a). "Din Felsefesi Nedir?”, (Editör Latif Tokat), Din Felsefesi içinde, Bilimsel Araştırma Yayınları, 15-38.

Tokat, Latif, (2018b). "Din, Estetik ve Sanat”, (Editör Latif Tokat), Din Felsefesi içinde, Bilimsel Araştırma Yayınları, 331-350.

Tüzer, İ. (2009). Kassandra Damgası'nın Eksiltilen Mesajı: Tevarüs Eden Kötülük ve Yeniden Doğan İnsan: "Uzay Rahibi Filofey”, (Editör Ramazan Korkmaz), Cengiz Aytmatov içinde, Kültür ve Turizm Bakanlığı Yayınları, 317-329.

Yağmur, O. (2008). Aytmatov-Yeni Çağın Mevlanası, Kardeş Kalemler Aylık Avrasya Edebiyat Dergisi, Y11: 2, Say1:19, 51-53.

Yetişken, H. (2012). Felsefe Edebiyat İliş̧kisinin Değeri, Kaygı Uludă̆ Üniversitesi Fen-Edebiyat Fakültesi Felsefe Bölümü Dergisi, 71-79.

Yılmaz, A. (2007). Bozkırda Yeşeren Sevda Türküleri -Aytmatov ve Eserleri Üzerine-, Ötüken Neşriyat.

Y1lmaz, B. D. (2015). Cengiz Aytmatov Kitabl, Atlas Kitap. 